\title{
Gene mutations in parasitic diseases Part II: Parasite gene mutations
}

Review

Article

\author{
Sherif M. Abaza ${ }^{1}$ and Manar M. S. El-Tonsy² \\ Parasitology Departments, Faculty of Medicine, ${ }^{1}$ Suez Canal and ${ }^{2}$ Ain Shams Universities, \\ Egypt
}

\begin{abstract}
Gene mutation may occur either in the parasite or in the host, which may be beneficial or harmful for each. As we previously discussed, part I covered causes and types of gene mutations as well as their relation(s) to or effect(s) on parasitic diseases; part II deals with parasite gene mutations. The most apparent manifestation is drug resistance especially with anti-malarial drugs for falciparum malaria. The majority of $P$. falciparum isolates are able to undergo gene mutations in genes encoding enzymes that control drug uptake. Parasite gene mutations are suggested to influence parasite virulence in toxoplasmosis and malignant malaria, and to have impact on the occurrence of malignancy in schistosomiasis and clonorchiasis. It is intended in the present review to present mechanism(s) of drug resistance due to parasite gene mutations, with special emphasis on anti-malarial drugs, albendazole, metronidazole, and other drugs used in treatment of African trypanosomiasis and toxoplasmosis. The review also presents other effects of parasite gene mutations on disease outcome and progress as well as occurrence of false diagnosis in falciparum malaria using ICTs utelizing histidine rich protein.
\end{abstract}

Key Words: Anti-parasitic drugs, drug resistance, gene mutation, false diagnosis.

Abbreviations: ART: Artemisinin; CQ: Chloroquine; crt: Chloroquine resistance transporter gene; dhfr: Dihydrofolate reductase gene; dhps: Dihydropteroate synthase gene; FAN: Fansidar; PYR: Pyrimethamine; mdr: Multi-drug resistance gene; SVMNT: crt gene mutations at codons 72-76 (Ser-Val-Met-Asn-Thr).

Received: 10 January 2017, Accepted: 7 March 2017.

Corresponding Author: Sherif M. Abaza, Tel. : +20-10-0524-3428, E-mail: smabaza@hotmail.com.

ISSN: 1687-7942, Vol. 10, No. $1 \& 2$.

1. Drug resistance: Drug resistance is one of the main obstacles in eradication of endemic parasitic diseases including malaria, schistosomiasis, visceral leishmaniasis, lymphatic filariasis, onchocercosis and African as well as American trypanosomiasis (Chagas' disease). By definition, it is "the ability of a parasite strain to survive and/or multiply despite the administration and absorption of a drug in doses equal to or higher than those usually recommended but within the limits of the subject tolerance" ${ }^{[1]}$. Therefore, it is attributed to inability of the resistant strains to uptake the drug due to mutations in the parasite genes encoding the enzymes responsible for the uptake. A classification system into sensitive (S) and three degrees of resistance (RI, RII, RIII) was introduced to monitor results of in vivo drug resistance test, based on the parasitologic response ${ }^{[1]}$.

1.1. Anti-malarial drugs: $P$. falciparum is a complex parasite with high plasticity in its genome. To survive, it is able to 1) delete certain portions of its genes that are unessential for its growth; 2) evade immune response by antigenic variations; and 3) undergo gene mutations in enzymes controlling drug uptake ${ }^{[2]}$. As a consequence of the strong selection force of anti-malarial drugs, resistance point mutations have spread through malaria parasite populations over the last 25 years $^{[3]}$. The dynamics of strong selection for parasite gene mutations and the obtained data indicated that the selection pressure on the drug-linked genes increased the spread of mutant $P$. falciparum isolates in the endemic areas. Frequent population-based studies were strongly recommended to evaluate the efficacy of anti-malarial drugs ${ }^{[4]}$. To identify gene mutations responsible for drug resistance in a locality, the following were recommended: 1) mapping a genetic data base for the known gene mutations; 2) identification of the putative drug-resistance loci in each gene; and 3) identification of the genetic basis (if present) to all novel drugs before clinical use ${ }^{[5]}$. In a meta-analysis study, 220 clinical, pharmacological, in vitro and molecular studies were analyzed. The reviewers claimed that these studies missed the limitations in standardization regarding different geographic locations and different methods for gene mutations detection. So, the worldwide anti-malarial resistance network (WWARN) designed a centralized resistance data network for these types of studies to present valuable resources to the health authorities for development of action plans that identify and combat anti-malarial drug resistance in their locality ${ }^{[6]}$. Another review article summarized mechanism(s) and genetic markers of chloroquine (CQ) resistance and their distribution frequencies in all endemic African, Asian and South American countries, with special emphasis in 
India $^{[7]}$. Several benefits materialized from investigating the genetic markers of drug resistance that frequently occurred in malaria chemotherapy. First, mapping the genetic epidemiological data for drug resistance gives a mirror image of parasite migration patterns of drug resistance ${ }^{[8]}$. In other words, leakage of parasite anti-malarial drug resistance from country to another should be considered and neighbor countries should implement regional rather than national policies to prevent genetic drug resistance spread between them ${ }^{[9]}$. Secondly, a baseline record is built before changing national drug therapy in an endemic locality. In this context, a study conducted in Pakistan revealed the presence of high CQ resistance, with absence of Fansidar (FAN) resistance ${ }^{[10]}$. Thirdly, investigating genetic markers provides the proficiency to describe drug status in a malariaendemic area. For example, a study conducted in Senegal investigating the prevalence of different genetic markers in P. falciparum isolates, concluded that there was: 1) a decreased level of CQ resistance; 2) an increased level of pyrimethamine (PYR) resistance; 3 ) a moderate resistance to amodiaquine; and 4) no resistance to $\mathrm{FAN}^{[11]}$. A study involving $P$. vivax isolates from China, also concluded relative susceptibility to CQ and FAN therapy ${ }^{[12]}$. Similarly, frequency distributions of the genetic markers linked to anti-malarial drug resistance in Haiti revealed normal CQ sensitivity ${ }^{[13]}$. Fourthly, the investigations showed that high prevalence of mutations in imported isolates indicated rapid development and spread of resistance against common anti-malarial drugs used nationally ${ }^{[14-16]}$. Lastly, several studies were conducted all over the world to investigate the efficacy of anti-malaria drugs and to regularly monitor their use. Mutations detected in certain $P$. falciparum genes were considered good predictors of potential FAN treatment failure in several countries ${ }^{[17-21]}$. In contrast, absence of mutations suggested use of FAN as first choice treatment in other areas ${ }^{[22,23]}$. Similarly, other investigators suggested that use of amodiaquine was no longer effective in Tanzania ${ }^{[24]}$ while combined atovaquone and proguanil therapy was efficient in Thailand ${ }^{[25]}$. In addition, it was recommended that both CQ and FAN should not be used in the near future in China ${ }^{[26]}$, and CQ was not effective in Malaysia ${ }^{[27]}$.Continuous investigation of $P$. vivax and $P$. falciparum molecular markers to monitor development of FAN resistance in Afghanistan isolates was recommended ${ }^{[28]}$. On the other hand, when CQ was replaced by artemisinin (ART) derivatives - combined therapy in treatment of uncomplicated falciparum malaria, the investigators detected known mutations frequently linked to anti-malaria drugs when combined with ART. Based on the obtained data, it was recommended to frequently monitor ART and the anti-malarial drugs in Zanzibar $^{[29]}$, China ${ }^{[30]}$, Cameroon ${ }^{[31]}$, India ${ }^{[32]}$, Equatorial Guinea $^{[33]}$, Tanzania ${ }^{[34]}$, Thailand ${ }^{[35]}$, and Central African Republic $^{[36]}$. In Yemen, which is a highly endemic area of falciparum malaria with high diversity, the investigators suggested that ART-combined therapy with FAN should be the first choice of malaria treatment ${ }^{[37]}$. Data obtained from two studies conducted in Equatorial Guinea showed high CQ resistance, and suggested use of ART-FAN combined therapy ${ }^{[38]}$ or lumefantrine and mefloquine ${ }^{[39]}$ as alternative drugs.

\section{-Dihydrofolate reductase (dhfr) and} dihydropteroate synthase (dhps) genes: Mutations in the $d h f r$ and dhps genes of $P$. falciparum parasites have been associated with decreased parasite sensitivity to the anti-folate drugs. Pyrimethamine and the biguanides bind to and inhibit the bifunctional enzyme dihydrofolate reductase (DHFR) ${ }^{[40]}$, and the sulfonamides and sulfones inhibit the enzyme dihydropteroate synthase (DHPS ${ }^{[41]}$. On investigating the association between antifolate (sulphadoxine) resistance and mutation of $d h p s$ gene in P. falciparum isolates from India in vitro, 5 mutations at codons 436, 437, 540, 581 and 613 were detected. The investigators detected quadruple mutant alleles in $36.7 \%$ of their isolates, and $\sim 97 \%$ of them were highly sulphadoxine resistant ${ }^{[42]}$.

On the other hand, $P$. falciparum isolates with mutation (serine $\rightarrow$ asparagine) at position 108 in $d h f r$ gene are resistant to PYR, while those with serine $\rightarrow$ threonine at the same codon associated with an alanine $\rightarrow$ valine substitution at position 16, are resistant to cycloguanil (the active metabolite of proguanil). In isolates resistant to both drugs, an additional $d h f r$ gene mutation (alanine $\rightarrow$ valine) at codon 164 is present ${ }^{[43]}$. Since then, several articles were published to estimate frequency distribution of gene mutation responsible for PYR resistance in several countries; Brazil ${ }^{[44]}$, New Guinea ${ }^{[45]}$, Tanzania ${ }^{[46]}$, and for proguanil resistance in 3 African countries (Niger, Senegal and Kenya) ${ }^{[47]}$. Resistance to both drugs was reported in Cameroonian isolates where the investigators found dhfr 108 point mutation in 14 out of 15 isolates resistant to both drugs ${ }^{[48]}$. In addition, another 2 mutations in $d h f r$ gene were found in P. falciparum strains isolated from Thailand with PYR resistance ${ }^{[49]}$. However, low level of PYR resistance was suggested in Haiti due to the presence of mutation in pfdhfr gene at codon 108 and the absence of other codons $(51,59$ and 164) with no mutations in dhps gene $^{[50]}$. In contrast, all $d h f r$ mutations were rarely detected in P. falciparum strains from 5 countries in Africa (Kenya, Tanzania, Malawi, Gabon, and Nigeria) where PYR was intensively used ${ }^{[51]}$.

Since the anti-malarial drug resistance for monotherapy has emerged, sulfadoxine is always provided in combination with PYR, known as SP (sulfadoxinepyrimethamine combined therapy) or FAN (fansidar). In Pakistan, a single gene mutation (C59R) at codon 16 in dhfr gene was reported as the first field sample of a mutant dhfr allele where the 108 codon is unchanged ${ }^{[52]}$. One year later, Camerionian investigators found three $d h f r$ gene point mutations at codons 51, 59 and 108 and assigned them as reliable genetic markers to predict FAN resistance 
in Africa ${ }^{[53]}$. Since then, several studies were conducted for genetic mutations in FAN resistance. Simultaneous presence of mutations at 51 and 108 in $d h f r$ gene and at 437 and 581 in dhps gene were associated with high FAN resistance in Uganda ${ }^{[54]}$ and Venezuela ${ }^{[55]}$. It was concluded from several studies that triple $d h f r$ gene mutations at codons 51, 59 and 108 with double dhps gene mutations were associated with mild and moderate FAN resistance in Kenya ${ }^{[56]}$, Cameroon ${ }^{[57]}$, Nigeria ${ }^{[58]}$, Ethiopia $^{[59]}$, Ghana ${ }^{[60]}$, Sri Lanka ${ }^{[61]}$ and Tanzania ${ }^{[62]}$. In one of these studies, the investigators claimed that the degree of association between gene mutation and drug resistance might vary regionally in the same country ${ }^{[60]}$. However, in a retrospective study conducted on Kenyan $P$. falciparum isolates from 2008 to 2012, the investigators concluded that triple $d h f r$ gene mutations with or without double $d h p s$ gene mutations were associated with FAN resistance ${ }^{[63]}$.

In Uganda, investigation of FAN resistance alone or in combination revealed that mutation in codon 540 of dhps gene is responsible for FAN resistance only, while the mutation in codon 59 of $d h f r$ mediated resistance to the drug whether alone or in combination ${ }^{[64]}$. P. falciparum strains isolated from patients from Burkina Faso showed that mutations at codons 108 or 59 in $d h f r$ gene would predict disease recrudescence after FAN treatment ${ }^{[65]}$. In other studies conducted in several African countries, the investigators suggested that the presence of triple mutations in both genes are genetic markers for FAN failure in pregnant women ${ }^{[66-68]}$. In Iran, mutations at codons 108 and 59 (dhfr) and 436 (dhps) were the commonest mutations associated with FAN resistance ${ }^{[69]}$. In the same country and after three years of FAN treatment against falciparum malaria, high frequency of double mutations at codons 59 and 108 of pfdhfr and single mutation at codon 437 of pfdhps genes was detected in $\sim 96 \%$ of the examined isolates. The investigators claimed that the parasite would potentially develop quintuple mutations, and advised the health authorities to monitor FAN clinical resistance at regular intervals ${ }^{[70]}$. In India, triple mutations in dhfr gene (codons 51, 59 and 108) and dhps genes (436, 437 and 540) were associated with PYR and sulphadoxine resistance, respectively; while $\sim 94 \%$ of the isolates with triple mutations in both genes were associated with high grade of FAN failure ${ }^{[71]}$. A novel mutation of isoleucine in $d h f r$ gene (codon 108) was also recorded in India for in vitro resistance of $P$. falciparum isolates to FAN treatment. The investigators found double isoleucine mutations at codons 108 and 51 in more than three quarters of the resistant isolates. Together with the double mutations, one of 4 mutations in dhps gene was detected at codons 436 or 437 or 581 or $613^{[72]}$. Due to the high frequency of mutations and the appearance of novel mutations in $d h f r$ and dhps genes, the investigators asked health authorities to stop FAN therapy in treatment of falciparum malaria in Malaysia ${ }^{[73]}$, Burkina Faso ${ }^{[74]}$ and Tanzania ${ }^{[75]}$. Moreover, two novel mutations of dhps gene at codons 540 and 588 were associated with FAN resistant $P$. falciparum isolates from Indonesia ${ }^{[76]}$. However, it was suggested that resistance to FAN does not occurr in the presence of mutation in pfdhfr gene at codon 108 and the absence of other codons (51, 59 and 164), with no mutations in dhps gene ${ }^{[50]}$. With ART-FAN combined therapy and shortly after its adoption in Afghanistan, the majority of $P$. falciparum isolates developed double mutation in $d h f r$ gene at codons 59 and 108, while the minority developed triple mutations in dhps gene at codons 437, 540 and 581. The investigators claimed that all these mutations were previously linked to FAN resistance ${ }^{[77]}$.

For $P$. vivax, three mutations at codons 57, 58, and 117 in $d h f r$ gene were associated with high levels of FAN resistance in several strains isolated from widely separated countries from Asia and Africa ${ }^{[78]}$. The occurrence of three mutations at the same codons, but in dhps gene, in some $P$. vivax isolates suggested their association with increased resistance to sulfadoxine treatment ${ }^{[79]}$, while increased frequency of mutations in both $d h f r$ and $d h p s$ genes was associated with selection imposed by FAN therapy ${ }^{[80]}$. In contrast, frequency distribution of mutations of $p v d h f r$ and pvdhps genes didn't exceed $50 \%$ in the studied isolates from China, a result suggesting relative susceptibility to FAN treatment ${ }^{[81]}$; while prevalence of these gene mutations for FAN resistance was low in Eastern and Central Sudan ${ }^{[82]}$. On the other hand, mutations at codons 58, 61 and 117 of pvdhfr gene were detected in PYR resistant isolates from China, and the most prevalent mutant allele was double mutations at 58 and $117^{[83]}$. A point mutation at codon 382 of $p v d h p s$ gene was detected associated with CQ resistance, but the investigators recommended further studies to confirm this association in larger samples from Brazil ${ }^{[84]}$.

-Multi-drug resistance (mdr) gene: It is also known as P-glycoprotein homolog 1 gene. There is much controversy regarding the point mutation (tyrosine $\rightarrow$ phenylalanine) at codon 86 in $m d r$ gene of $P$. falciparum isolates and its link to $\mathrm{CQ}$, mefloquine and halofantrine resistance in vitro. Some studies attributed this mutation to all mentioned drugg $^{[85,86]}$ and they considered it as a useful genetic marker to predict drug resistance levels if influenced by the history of drug selection of each population ${ }^{[87-89]}$. Moreover, double pfmdr 1 mutation at codons 86 and 1246 was associated with the early CQ treatment failure in vivo ${ }^{[90]}$. In contrast, others were in incomplete agreement, and suggested that other genetic factors with $m d r$ point mutation might be involved in CQ or mefloquine resistance in Africa ${ }^{[91,92]}$, and Asia ${ }^{[93-95]}$. Also, no association was observed between $p f m d r 1$ mutations and resistance to quinine, mefloquine and ART in Brazil ${ }^{[96]}$. However, a strong association was detected between $m d r 86$ mutation and increased sensitivity to mefloquine and halofantrine in Gambia ${ }^{[97]}$. For P. vivax, gene mutation at $p v m d r 1$ gene was found inappropriate to monitor CQ resistance in Madagascar ${ }^{[98]}$. Furthermore, in spite of presence of mutation (codon 1076) in $p v m d r 1$ gene 
in the majority of isolates investigated in vivo and in vitro drug studies, still all the Indian isolates were susceptible to $\mathrm{CQ}^{[99]}$.

-Chloroquine resistance transporter (crt gene): Several studies showed that mutation at codon 76 in $P$. falciparum CQ resistance transporter ( $p f c r t$ ) gene encoding digestive-vacuole transmembrane proteins was linked with CQ resistance in Africa $^{[100-102]}$, and Asia ${ }^{[103-107]}$. However, discrepancy between resistant P. falciparum strains (14\%) and the frequency of the mutant crt at codon 76 (92\%), suggested that other factors might be involved in CQ resistance in Tanzania ${ }^{[108]}$. In a study conducted in Afghanistan, high prevalence of amodiaquine resistance in vivo was associated with mutation in pfcrt gene at codons 72-76 (SVMNT; i.e. Ser-Val-MetAsn-Thr ${ }^{[109]}$. Moreover, after 10 years of CQ withdrawal because of drug failure, single mutation (K76 CQ) and double mutations (K76T and C72S) in pfcrt were detected in $84 \%$ and $3 \%$ of Ethiopian $P$. falciparum isolates, respectively. As these mutations were more linked to isolates sensitive to $C Q$, the investigators anticipated the recurrence of CQ-sensitive isolates and that $\mathrm{CQ}$ should be considered as alternative therapy in CQ-based combination therapy ${ }^{[110]}$. On the other hand, the codon 76 mutation was detected in pfcrt gene of all of 96 samples isolated in Brazil in spite of CQ withdrawal from treatment since $\sim 35$ years, while it was still CQ-resistant ${ }^{[96]}$. Recently in Yemen, mutations of crt gene (codons 76, 271, 326 and 371) were highly associated with CQ resistance after 4 years of treatment shift to ART combinations, and the investigators asked Health authorities to forbid the use of CQ in falciparum malaria with its careful use in vivax malaria $^{[111]}$.

-Combined genetic factors: Detection of combined mutations in $p f c r t$ (codon 76) and in $p f m d r 1$ (codon 86) were used to monitor development and spread of amodiaquine resistance in Africa ${ }^{[112]}$. In Burkina Faso, mutation at $p f c r t$ (76) or $p f m d r 1$ (86 or 1246) predicted recrudescence after amodiaquine treatment ${ }^{[65]}$. Both mutations were associated with amodiaquine and desethylamodiaquine resistance in Colombia ${ }^{[113]}$, while in Nigeria, they were associated with amodiaquine in vitro resistance ${ }^{[14]}$. It was also confirmed that high prevalence of the mutations at $p f c r t$ SVMNT and $p f m d r 1$ at codon 86 was associated with high levels of CQ resistance and the investigators suggested their association with reduced efficacy of amodiaquine in Angola ${ }^{[115]}$. Meanwhile, mutations at codons 76 and 86 in $p f c r t$ and $p f m d r 1$ genes respectively, were present together in CQ resistant isolates in India ${ }^{[116-118]}$. However, mutations at codons 97 and 184 in $p f c r t$ and $p f m d r 1$ genes, respectively influenced the level of CQ resistance in Thailand ${ }^{[119]}$. In contrast, results of a study conducted in Philippine, isolates showed that both mutations were not predictive of in vitro $\mathrm{CQ}$ resistance ${ }^{[120]}$. The mutation at codon 423 in $p f m d r 2$ and 51 and 59 or 108 in pfdhfr were independently associated with in vitro PYR resistance in Thailand ${ }^{[121]}$. For
P. vivax, neither of $p v m d r 1$ nor $p v c r t$ genes mutations were associated with CQ resistance in Brazil ${ }^{[122]}$. High frequency distribution of mutations in $p v m d r 1$ and pvcrt genes were associated with CQ resistance in the majority of $P$. vivax isolates from Ethiopia ${ }^{[123]}$.

-Other genetic markers: Three mutations were detected in cytochrome b (cyt b) gene which resulted in resistance of $P$. berghei to atovaquone in vitro ${ }^{[124]}$. P. falciparum showed a mutation at codon $268(\mathrm{Tyr} \rightarrow \mathrm{Ser})$ of the $c y t b$ gene after atovaquone-PYR combined treatment failure ${ }^{[125]}$. Another mutation at the same codon (Tyr $\rightarrow$ Asn) was detected in a patient with atovaquone/proguanil (Malarone) therapy failure ${ }^{[126]}$. Similarly, the highest atovaquone resistance in $P$. falciparum Indonesian isolates carried both mutations at codon $268^{[127]}$. In contrast, only one study denied involvement of cytochrome $b$ in atovaquone-proguanil resistance in P. falciparum isolates from Angola ${ }^{[128]}$.

Twelve point mutations in $c g 2$ gene, which is a candidate for $\mathrm{CQ}$ resistance, was associated with in vitro resistance of $P$. falciparum strains to $\mathrm{CQ}^{[129]}$. The same investigators found that CQ resistant isolates had 16 repeat units in one of the polymorphic regions (omega region) of $c g 2$ gene, while CQ-sensitive ones had either $\leq 15$ or $\geq$ 17 repeat units, but they recommended further studies on a larger number of isolates to consider this mutation as a reliable genetic marker for CQ resistance ${ }^{[130]}$.

P. falciparum sodium hydrogen exchanger ( $p f n h e$ ) gene is another gene investigated with pfcrt-76 and pfmdr1-86 and their association with resistance against quinine, mefloquine and halofantrine in vitro. The results showed the importance of $p$ fnhe with $p f m d r 1$ (codon 86) mutations as indicators of reduced quinine susceptibility ${ }^{[131]}$. In studies conducted in China ${ }^{[132]}$ and Viet $\mathrm{Nam}^{[133]}$, the obtained results supported the association of $p f n h e$ gene mutation in quinine resistance. In contrast, results from a study conducted in Thailand showed much doubt in the usefulness of $p$ fnhe 1 gene as genetic marker for quinine resistance in vitro ${ }^{[134]}$.

On the other hand, no association was detected between mutation of sarcoplasmic and endoplasmic reticulum $\mathrm{Ca}^{2+}$ ATPase (pfatp6) gene and in vitro susceptibility of $P$. falciparum isolates to $\mathrm{CQ}$, mefloquine and quinine ${ }^{[135]}$. In 2014 came the first study investigating $P$. falciparum multidrug resistance protein-2 (mrp2) gene and its association with anti-malarial drugs in Thailand. The investigators found frequent and complex variations, including single nucleotide polymorphisms (SNPs) and polymorphic microindels (Mis) which were associated with quinolines (CQ, piperaquine and mefloquine) in vitro[136]

-Resistance to ART derivatives: Search for genetic markers associated with resistance to ART started in 2006. No mutation was detected in $m d r 1, c g 10$ and genes 
controlling translational controlled tumor protein ( $t c t p)$, and atp6 genes, when the investigators sequenced these genes in $P$. chabaudi grown in increasing ART concentrations ${ }^{[137]}$. The first report was published on a field isolate resistant to ART in the Cambodian population ${ }^{[138]}$. This was followed later by two publications; the first discussed ART resistance in Weastern borders of Thailand ${ }^{[139]}$, while the second dealt with reduced susceptibility to ART in Southern Myanmar ${ }^{[140]}$. Negative data were obtained also on investigating $p f m d r 1$, pfatp 6 , mitochondrial genome and the gene encoding deubiquitinating enzyme $(u b p 1)^{[141]}$. There was diverse genetic mutations in atp6 gene that enabled the investigators to conclude its negative association with ART resistance ${ }^{[142-147]}$. In addition, the frequency distribution of mutations of the genes $p f m d r 1$ (6 codons), pfcrt (codon 76) and multidrug resistance protein 1 (pfmrp 1 ) (5 codons) were significantly unchanged after 4 years of ART combined treatment in $\operatorname{Iran}^{[148]}$. However, 6 mutations at $P$. falciparum atp 6 gene were detected as baseline data before starting ART treatment in Niger. Three of them were newly detected while the mutation at codon codon 569 was the most predominant ${ }^{[149]}$. After three years of administration of ART-FAN combination in treatment of falciparum malaria in Sudan (2004-2007), high frequency $(72-75 \%)$ of point mutations at pfcrt (codon 76), pfdhfr (codons 51 and 108) and pfdhps (codon 436) was detected. Frequency of $p f m d r 1$ gene mutation was $\sim 55 \%$, while almost the whole studied population harbored the wild type allele of pfatp6. The investigators advised the national health authorities to regularly monitor ART-based combination therapy especially in endemic areas of Sudan ${ }^{[150]}$.

In the last decade, two genes were incriminated in ART resistance; cysteine protease falcipain-2 ( $f p 2)$ and Kelch-domain 13 (kelch13). Only one article reported $f p 2$ gene as genetic marker for resistance to ART; and the investigators found that this mutation was not prevalent in Uganda ${ }^{[151]}$. Kelch-domains are proteins whose interruption results in a wide variety of different organism phenotypes through protein degradation. It was found that some $P$. falciparum isolates from Southeast Asia and resistant to ART derivatives, have kelch 13 mutations ${ }^{[152]}$. One of the main ART actions is to obligate ring stages to enter the dormant phase, facilitating their clearance by the host immune system and spleen; and mutations in kelch 13 gene prevent ring stages from responding to oxidative stress clearing ${ }^{[153]}$. Investigating kelch 13 gene in $P$. falciparum isolated from patients from 7 Asian and 3 African countries revealed its involvement in ART derivatives resistance. The investigators recommended prolonged ART-based combination courses in patients with standard 3-day treatments failures ${ }^{[154]}$. Several studies were conducted to confirm this link in $P$. falciparum strains isolated from several Asian countries; Bangladesh ${ }^{[155]}$, China and Myanmar ${ }^{[156-159]}$. On the other hand, its mutation was not prevalent in several African countries; Uganda ${ }^{[151]}$, Senegal ${ }^{[160]}$ and Mali ${ }^{[161]}$. Neither of the mutations detected in Cambodia nor in Southeast Asia were detected in isolates from Sub-Saharan African countries; instead the investigators detected several novel mutations, but in very low frequencies ${ }^{[162]}$

\subsection{Other anti-parasitic drugs}

-Drugs for schistosomiasis: In 1989, American investigators found an association of BamHI fragment in the oxamniquine resistant $S$. mansoni strains ${ }^{[163]}$. The same researchers investigated the molecular characterization generating this fragment in resistant strains and they compared the genomic DNA from resistant and sensitive strains. They suggested that a drug induced parasite genomic alteration produced this fragment in resistant strains $^{[164]}$. Two years later, a group of scientists from Italy analyzed the genetic behavior responsible for oxamniquine resistant strains. Their results showed that schistosomes sensitivity to the drug was strictly related to specific chromosome(s) in a dominant gene encoding the enzyme that converts the drug to reactive ester ${ }^{[165]}$.

-Albendazole: Albendazole resistance in giardiasis was conducted in vitro and it was demonstrated that mutation of the $\beta$-tubulin gene was not involved in the resistance. An alternative mechanism of resistance involving the cytoskeletal structure, particularly the median body, was suggested. This was attributed to evident major chromosome rearrangements indicating differences in the cytoskeleton between sensitive and resistant lines ${ }^{[166]}$. On the other hand, Jiménez-Cardoso et al. ${ }^{[167]}$ found several mutations in the $\beta$-giardin gene in both albendazoleresistant and recovered-sensitive $G$. lamblia strains indicating that resistance to albendazole is not necessarily caused by mutations in the $\beta$-giardin gene of G. lamblia.

-Metronidazole: Orozco et al. ${ }^{[168]}$ reviewed multi-drug resistance in amoebiasis, and it was attributed to mutation of Entamoeba histolytica P-glycoprotein-like gene (EhPgp). However, several studies showed metronidazole resistance in intestinal giardiasis and amoebiasis as well as in cases of vaginal trichomoniasis ${ }^{[169-171]}$. In 1992, a study was conducted to investigate the role of ferredoxin gene mutation in $T$. vaginalis metronidazole-resistant isolates, and the investigators detected decreased ferredoxin levels in $50-65 \%$ of the resistant isolates. The investigators hypothesized that ferredoxin gene mutation could be implicated in metronidazole resistant clinical cases of trichomoniasis. They explained that ferredoxin gene mutation resulted in decrease of intracellular ferredoxin expression with a decrease in regulatory protein binding affinity; which would lead to inability of metronidazole activatation in its cytotoxic form ${ }^{[172]}$. In 2000, an American study was conducted to investigate metronidazole T. vaginalis resistant isolates. A point mutation at the position 66 of the internal transcribed spacer 1 (ITS1) fragment was detected in 16 out of 109 isolates $(\sim 15 \%)$, and T. vaginalis virus (TVV) was detected in $\sim 50 \%$ of 
their isolates. Correlating these data with metronidazole resistance, the investigators concluded that isolates with TVV and ITS1 fragment mutation are significantly more likely to be sensitive and resistant to metronidazole ${ }^{[173]}$. In 2009; it was shown that metronidazole-resistant isolates of G. lamblia, Entamoeba spp.and T. vaginalis have different combinations of gene mutations either similar to the metronidazole-resistant anaerobic bacteria Helicobacter pylori in nitroreductase (ntr) gene or to Bacteroides fragilis in nitroimidazole ( $\mathrm{nim}$ ) gene ${ }^{[174]}$. In two Iranian studies, the investigators detected point mutation at 209 of the ITS1 fragment in $3.9 \% \%^{[175]}$, and at position 239 of ferredoxin gene in $8.7 \% \%^{[176]}$ of their $T$. vaginalis isolates.

-Drugs for African trypanosomiasis: The link between mutations in tbat 1 gene encoding P2 adenosine transporter $(\mathrm{P} 2)$ in variant $T$. gambiense isolates from Uganda and melarsoprol resistance was investigated. It was found that $58 \%$ of the resistant isolates had tbat 1 gene mutation. Although $58 \%$ of the resistant isolates had tbat 1 gene mutation, several patients with relapse after melarsoprol therapy had the wild-type tbat 1 gene. The investigators suggested that tbat 1 gene mutations was not the only mechanism behind melarsoprol resistance or failure $^{[177]}$. Two years later, another group of researchers investigated whether other factors contribute with tbat 1 gene in $\mathrm{P} 2$ activity responsible for mediation of melarsoprol uptake. Their hypothesis allowed them to identify and characterize two additional drug transport activities, a high-affinity and a low-affinity component of pentamidine transport (HAPT1 and LAPT1). Inhibition analysis of both factors confirmed the contribution of HAPT1 in P2 activity ${ }^{[178]}$. In contrast, a study conducted in South Sudan observed that all resistant isolates were sensitive to the drug in vitro and in experimentally infected mice. The investigators also did not detect any of the previously described point mutations in tbat 1 gene in their isolates, and they concluded the irresponsibility of drug resistance to melarsoprol failures ${ }^{[179]}$. However, data obtained from a study conducted on animal trypanosomiasis resistant to diminazene aceturate revealed that mutations in genes controlling P2 transporter favors parasite survival (i.e. drug resistance ${ }^{[180]}$. In 2013, aquaglyceroporin transporter (TbAQP2) was identified as another transporter involved in melarsoprol/pentamidine resistance. It was found that mutations in the gene encoding TbAQP2 significantly correlated with pentamidine and melarsoprol resistance in the clinical isolates ${ }^{[181]}$. On the other hand, isometamidium is a veterinary drug used against African trypanosomiasis, targeting the trypanosomes kinetoplast. British investigators screened mutations in 30 genes and 3 protein complexes associated with kinetoplast-dependent growth to investigate the link between gene mutation and isometamidium resistance. They observed that nonmitochondrial proteins and multi-subunit complexes were implicated in kinetoplast-independent growth, and mutations in their encoding genes might correlate with isometamidium resistance. The investigators also discussed failure of other drugs used in some flagellated protozoa to attack their kinetoplast ${ }^{[182]}$.

-Drugs for toxoplasmosis: Parasitic gene mutations incriminated in drug resistance included cytochrome b, dhfr and dhps genes for atovaquone ${ }^{[183]}, \mathrm{PYR}^{[184]}$ and sulfonamide ${ }^{[185]}$. In contrast, a French study investigated the previous drugs against $17 \mathrm{~T}$. gondii isolates in vitro, and they observed some variability in the susceptibilities of these isolates to atovaquone and PYR, with neither clear evidence of drug resistance, nor defined mutations in the studied genes. On the other hand, they detected 3 strains resistant to sulfadiazine, with several identical mutations in dhps gene ${ }^{[186]}$. Recently, another group of French investigators denied the link between sulfadiazine resistance and polymorphisms or overexpression in $d h f r$, dhps and $\mathrm{ABC}$ transporter genes family. They recommended further studies to investigate mechanism of sulfadiazine resistance in toxoplasmosis and the genes associated with it ${ }^{[187]}$.

-Drugs for leishmaniasis: Drug resistance and its relations to parasitic gene mutations in leishmaniasis is a complex phenomenon of distinct genetic diversities. Since the 1990s, several studies were conducted investigating this strange relationship. Mutations in genes encoding pteridine reductase 1 (ptr 1 gene) ${ }^{[188]}$, mitochondrial apocytochrome $\mathrm{b}$ (cyb gene $)^{[189]}$, P-glycoprotein gene (pgpa gene) ${ }^{[190]}$, and topoisomerase I gene ${ }^{[191]}$ were incriminated in resistance of Leishmania spp. to methotrexate, antimycin A, oxyanions and 3, 3'-Diindolylmethane (DIM), respectively. Two Brazilian studies detected mutations at the genes encoding heat shock protein $70^{[192]}$, and aquaglyceroporin 1 (aqp 1 gene) ${ }^{[193]}$ contributed to resistance to antimonial drugs. However, three different mutations in the genes encoding the metabolic enzymes uracil phosphorybosyl transferase (UPRT), thymidine kinase (TK) and uridine phosphorylase (UP) were detected in $L$. infantum resistant to pyrimidine analogue 5-fluorouracil (5-FU) ${ }^{[194]}$. In contrast, no gene mutation was detected in paromomycin resistant $L$. tropica strains on nucleotide sequencing at both the DNA and RNA levels ${ }^{[195]}$. An Indian study denied the presence of point mutations in the miltefosine transporters (ldmt and ldros 3 genes) previously reported in parasites with experimentally induced miltefosine resistance in their clinical isolates ${ }^{[196]}$.

-Other anti-parasitic drugs: In a short report, Japanese investigators found cytochrome $\mathrm{b}(c y t b)$ gene mutation in Babesia gibsoni strains isolated from infected dogs that resist treatment with atovaquone ${ }^{[197]}$. American investigators applied real time PCR assays to screen development of benzimidazoles resistance in Ancylostoma caninuminfected dogs. They found elevated levels of $\beta$-tubulin isotype- 1 gene polymorphisms at codon positions 167,198 and 200 in hookworm resistant strain ${ }^{[198]}$. $\beta$-tubulin gene isoform 2 was also incriminated in benzimidazole resistant Echinococcus granulosus strains in post-surgical treatment of hydatid cyst in a study conducted in India ${ }^{[199]}$. On the 
other hand, only two studies were conducted to investigate parasite gene mutation and drug resistance in Chagas disease. While one study did not detect any association of drug resistance and P-glycoprotein ( $p g p$ gene $)^{[200]}$, another study found acquired mutations in the gene encoding mitochondrial $n t r$ gene and T. cruzi-resistant strains to benznidazole ${ }^{[201]}$

\section{Virulence, pathogenesis and clinical manifestan tions}

-Toxoplasmosis: In congenital toxoplasmosis, the relationship between $T$. gondii virulence measured by newborn clinical manifestations, and allelic polymorphism in $d h f r$ gene was investigated. The French investigators found that mutated clones with allelic replacement at certain loci $(36,83$ or 245$)$ of the tested gene displayed different outcomes suggesting a clear difference between virulence of wild and mutant types ${ }^{[202]}$. Several studies were conducted to screen $T$. gondii mutants using modified signature-tagged mutagenesis. This approach allowed the investigators to monitor in vitro growth of the mutants as well as their virulence and pathogenesis in vivo (animal model). When they detected mutants with growth impairment or low virulence, genetic complementation was done to identify genes required for $T$. gondii growth, virulence and pathogenesis. The investigators identified genes encoding regulators of chromosome condensation 1 (RCC1), patatin-like protein, proteophosphoglycan and transmembrane pellicle protein 1 (TPP1) as essential genes for $T$. gondii growth and virulence ${ }^{[203]}$, its survival and replication in activated macrophages ${ }^{[204]}$, bradyzoite development ${ }^{[205]}$, and virulence and invasion during acute toxoplasmosis ${ }^{[206]}$.

-Malaria: On investigating the relation between mutations in Pfcrt and Pfmdrl genes and clinical status (severe or uncomplicated falciparum malaria), all isolates had Pfcrt (codon 76 ) and $\sim 80 \%$ had Pfmdrl double mutations (codons 86 and 184), whatever their clinical status $^{[207]}$. Similarly, gene mutations incriminated in CQ and antifolate drug resistance had no association with complicated malaria ${ }^{[208]}$. In contrast, there was significant association of Pfcrt (codon 76) mutation and malaria severity in both groups of patients (children 5 years or younger and above 5 years ${ }^{[209]}$.

\section{Carcinogenesis}

In a study conducted in Japan to evaluate the mutagenic activity of $S$. japonicum and $C$. sinensis crude extracts (adult and egg antigens) and their ability to induce tumor cells, the investigators found weak but significant activity reaction only to $S$. japonicum soluble egg extract suggesting its ability to promote induction of tumor cells ${ }^{[210]}$. Other Japanese investigators suggested low possibility of immediate gene mutation related to worm and/or egg extracts of S. haematobium and S. mansoni leading to carcinogenesis ${ }^{[211]}$.

\section{False diagnosis}

Deletion or mutation in the gene encoding histidinerich protein 2 (HRP2) was attributed to false diagnosis of falciparum malaria cases using rapid diagnostic tests $^{[212-217]}$

\section{Concluding remarks}

1. In drug resistance against anti-malaria drugs, molecular, genetic and biochemical analyses showed several criteria. 1) Impaired CQ uptake by the parasite vacuole is a common characteristic of resistant strains, and this phenotype is associated with mutations of the $P f m d r 1, P f c g 2$ and Pfcrt genes. 2) One to four point mutations of $d h f r$ gene produce a moderate to high level of resistance to antifolates (PYR and proguanil). 3) Frequency of CQ resistant mutants varies among isolated parasite populations, while resistance to antifolates is highly prevalent in most malarial endemic countries. 4) The mechanism of resistance to sulfonamides and sulfones involves mutations of dhps gene. 5) Resistance to FAN is associated with $d h f r$ gene mutations at codons 51, 59 and 108, and dhps gene mutations at codons 436, 437 and 540. 5) There is much controversy regarding gene mutations linked to resistance to quinine, mefloquine and halofantrine.

2. Regarding flagellated parasites, mutation in the gene encoding $\beta$-giardin may be involved in albendazole resistance in giardiasis, while two genes are suggested for metronidazole resistance in trichomoniasis, mutation in ferredoxin gene and ITS1 fragment. In African trypanosomiasis, there is still much controversy regarding the link between tbat 1 gene (encoding P2 adenosine transporter) and melarsoprol, while aquaglyceroporin transporter involvement was recently identified in melarsoprol/pentamidine resistance. On the other hand, drug resistance and gene mutations in leishmaniasis showed some complexity due to distinct genetic diversities. However, mutations of the genes encoding heat shock protein 70 , aquaglyceroporin transporter 1 , and miltefosine transporters (ldmt and ldros3 genes) contribute to antimonial drugs and miltefosine resistance, respectively.

3. In congenital toxoplasmosis, mutation in $T$. gondii dhfr gene is suggested for strain virulence affecting the newborn outcome more than the wild strains. Certain genes encoding certain proteins and receptors were identified for T. gondii growth, virulence, survival and replication and bradyzoite development.

4. Mutation in the gene encoding histidine-rich protein 2 (HRP2) is incriminated in false diagnostic results 
using immunochromatographic tests (ICTs) in falciparum malaria.

\section{REFERENCES}

1. Le Bras J, Basco LK, de Pécoulas PE. Mechanisms and epidemiology of resistances to antimalarials. CR Seances Soc Biol Fil 1996; 190(4): 471-485.

2. Sharma YD. Genetic alteration in drug resistance markers of Plasmodium falciparum. Indian J Med Res 2005; 121(1): 13-22.

3. Picot S, Olliaro P, de Monbrison F, Bienvenu AL, Price RN, Ringwald P. A systematic review and metaanalysis of evidence for correlation between molecular markers of parasite resistance and treatment outcome in falciparum malaria. Malar J 2009; 8: 89.

4. McCollum AM, Schneider KA, Griffing SM, Zhou Z, Kariuki S, Ter-Kuile F et al. Differences in selective pressure on dhps and dhfr drug resistant mutations in western Kenya. Malar J 2012; 11: 77.

5. Anderson T, Nkhoma S, Ecker A, Fidock D. How can we identify parasite genes that underlie antimalarial drug resistance? Pharmacogenomics 2011;12(1): 5985 .

6. Sridaran S, McClintock SK, Syphard LM, Herman KM, Barnwell JW, Udhayakumar V. Anti-folate drug resistance in Africa: meta-analysis of reported dihydrofolate reductase $(d h f r)$ and dihydropteroate synthase (dhps) mutant genotype frequencies in African Plasmodium falciparum parasite populations. Malar J 2010; 9: 247.

7. Awasthi G, Das A. Genetics of chloroquine-resistant malaria: a haplotypic view. Mem Inst Oswaldo Cruz 2013; 108(8): 947-961.

8. Pearce RJ, Pota H, Evehe MS, Bâ el-H, MomboNgoma G, Malisa AL et al. Multiple origins and regional dispersal of resistant dhps in African Plasmodium falciparum malaria. PLoS Med 2009; 6(4): e1000055.

9. Bridges DJ, Molyneux M, Nkhoma S. Low level genotypic chloroquine resistance near Malawi's northern border with Tanzania. Trop Med Int Health 2009; 14(9): 1093-1096.

10. Ghanchi NK, Ursing J, Beg MA, Veiga MI, Jafri S, Mårtensson A. Prevalence of resistance associated polymorphisms in Plasmodium falciparum field isolates from southern Pakistan. Malar J2011; 10:18.

11. Wurtz N, Fall B, Pascual A, Diawara S, Sow K, Baret E et al. Prevalence of molecular markers of Plasmodium falciparum drug resistance in Dakar, Senegal. Malar J 2012; 11: 197.

12. Lu F, Wang B, Cao J, Sattabongkot J, Zhou H, Zhu $\mathrm{G}$ et al. Prevalence of drug resistance-associated gene mutations in Plasmodium vivax in Central China. Korean J Parasitol; 2012; 50(4): 379-384.

13. Elbadry MA, Existe A, Victor YS, Memnon G, Fukuda M, Dame JB et al. Survey of Plasmodium falciparum multidrug resistance-1 and chloroquine resistance transporter alleles in Haiti. Malar J 2013; 12: 426.

14. Gascón J, Mayor A, Mühlberger N, PeyerlHoffmann G, Oliveira I, Dobaño C et al. Molecular epidemiological surveillance of markers for antimalarial drugs in Plasmodium falciparum isolates imported to Barcelona, Spain. Med Clin (Barc) 2005; 125(8): 286-289.

15. Menegon M, Sannella AR, Severini C, Paglia MG, Matteelli A, Caramello $\mathrm{P}$ et al. Molecular epidemiology of imported malaria in Italy: the use of genetic markers and in vitro sensitivity test in a study of chloroquine resistance in Plasmodium falciparum. Ann Ist Super Sanita; 2006; 42(2): 203-210.

16. Amor A, Toro C, Fernández-Martínez A, Baquero M, Benito A, Berzosa P. Molecular markers in Plasmodium falciparum linked to resistance to antimalarial drugs in samples imported from Africa over an eight-year period (2002-2010): impact of the introduction of artemisinin combination therapy. Malar J 2012; 11: 100.

17. Gesase S, Gosling RD, Hashim R, Ord R, Naidoo $\mathrm{I}$, Madebe $\mathrm{R}$ et al. High resistance of Plasmodium falciparum to sulphadoxine/pyrimethamine in northern Tanzania and the emergence of dhps resistance mutation at Codon 581. PLoS One 2009; 4(2): e4569.

18. Bacon DJ, Tang D, Salas C, Roncal N, Lucas C, Gerena $\mathrm{L}$ et al. Effects of point mutations in Plasmodium falciparum dihydrofolate reductase and dihydropterate synthase genes on clinical outcomes and in vitro susceptibility to sulfadoxine and pyrimethamine. PLoS One 2009; 4(8): e6762.

19. Galindo JA, Cristiano FA, Knudson A, Nicholls RS, Guerra AP. Point mutations in dihydrofolate reductase and dihydropteroate synthase genes of Plasmodium falciparum from three endemic malaria regions in Colombia. Biomedica 2010; 30(1): 56-64.

20. Spalding MD, Eyase FL, Akala HM, Bedno SA, Prigge $\mathrm{ST}$, Coldren RL et al. Increased prevalence of the pfdhfr/phdhps quintuple mutant and rapid emergence 
of pfdhps resistance mutations at codons 581 and 613 in Kisumu, Kenya. Malar J 2010; 9: 338.

21. Abdullah NR, Norahmad NA, Jelip J, Sulaiman LH, Mohd Sidek H, Ismail Z et al. High prevalence of mutation in the Plasmodium falciparum dhfr and dhps genes in field isolates from Sabah, Northern Borneo. Malar J 2013; 12: 198.

22. Zakeri S, Afsharpad M, Raeisi A, Djadid ND. Prevalence of mutations associated with antimalarial drugs in Plasmodium falciparum isolates prior to the introduction of sulphadoxine-pyrimethamine as firstline treatment in Iran. Malar J 2007; 6: 148.

23. Hailemeskel E, Kassa M, Taddesse G, Mohammed H, Woyessa A, Tasew G et al. Prevalence of sulfadoxinepyrimethamine resistance-associated mutations in $d h f r$ and dhps genes of Plasmodium falciparum three years after SP withdrawal in Bahir Dar, Northwest Ethiopia. Acta Trop 2013; 128(3): 636-641

24. Lemnge M, Alifrangis M, Kafuye MY, Segeja MD, Gesase S, Minja D et al. High reinfection rate and treatment failures in children treated with amodiaquine for falciparum malaria in Muheza villages, Northeastern Tanzania. Am J Trop Med Hyg 2006; 75(2): 188-193.

25. Khositnithikul R, Tan-Ariya $\mathrm{P}$, Mungthin $\mathrm{M}$. In vitro atovaquone/proguanil susceptibility and characterization of the cytochrome $b$ gene of Plasmodium falciparum from different endemic regions of Thailand. Malar J 2008; 7:23.

26. Zhang GQ, Guan YY, Zheng B, Wu S, Tang LH. Molecular assessment of Plasmodium falciparum resistance to antimalarial drugs in China. Trop Med Int Health 2009; 14(10): 1266-1271.

27. Norahmad NA, Abdullah NR, Yaccob N, Jelip J, Dony $\mathrm{JF}$, Ruslan KF et al. High prevalence of pfcrt K76t mutants among Plasmodium falciparum isolates from Sabah, Malaysia.Southeast Asian J Trop Med Public Health 2011; 42(6): 1322-1326.

28. Zakeri S, Afsharpad M, Ghasemi F, Raeisi A, Safi N, Butt W et al. Molecular surveillance of Plasmodium vivax $d h f r$ and dhps mutations in isolates from Afghanistan. Malar J 2010, 9: 75.

29. Fröberg G, Jörnhagen L, Morris U, Shakely D, Msellem MI, Gil JP et al. Decreased prevalence of Plasmodium falciparum resistance markers to amodiaquine despite its wide scale use as ACT partner drug in Zanzibar. Malar J 2012; 11: 321

30. Huang F, Tang L, Yang H, Zhou S, Liu H, Li J, Guo S. Molecular epidemiology of drug resistance markers of
Plasmodium falciparum in Yunnan Province, China. Malar J 2012, 11: 243.

31. Menard S, Morlais I, Tahar R, Sayang C, Mayengue PI, Iriart X et al. Molecular monitoring of Plasmodium falciparum drug susceptibility at the time of the introduction of artemisinin-based combination therapy in Yaoundé, Cameroon: implications for the future. Malar J 2012; 11: 113.

32. Saha P, Guha SK, Das S, Mullick S, Ganguly S, Biswas A et al. Comparative efficacies of artemisinin combination therapies in Plasmodium falciparum malaria and polymorphism of pfATPase6, pfcrt, $p f d h f r$, and $p f d h p s$ genes in tea gardens of Jalpaiguri District, India. Antimicrob Agents Chemother 2012; 56(5): 2511-2517.

33. Fernández-Martínez A, Mula $\mathrm{P}$, Cravo $\mathrm{P}$, Charle P, Amor A, Ncogo P et al. Characterization of the Plasmodium falciparum sarcoplasmic/endoplasmic reticulum $\mathrm{Ca} 2+-A T P a s e$ gene in samples from Equatorial Guinea before implementation of artemisinin-based combination therapy. Am J Trop Med Hyg 2013; 88(1): 43-47.

34. Malmberg M, Ngasala B, Ferreira PE, Larsson E, Jovel I, Hjalmarsson A et al. Temporal trends of molecular markers associated with artemether-lumefantrine tolerance/resistance in Bagamoyo district, Tanzania. Malar J 2013; 12: 103.

35. Muhamad P, Chaijaroenkul W, Phompradit P, Rueangweerayut R, Tippawangkosol $\mathrm{P}$ et al. Polymorphic patterns of pfcrt and pfmdr1 in Plasmodium falciparum isolates along the ThaiMyanmar border. Asian Pac J Trop Biomed 2013; 3(12): 931-935.

36. Nambei WS, Lango Yaya E, Pounguinza S, Achonduh $\mathrm{O}$, Bogon A, Lengande R et al. Efficacy and safety of antimalarial combinations for treatment of uncomplicated malaria in children in Bangui, Central African Republic. Med Sante Trop 2013; 23(3): 313319.

37. Al-Hamidhi S, Mahdy MA, Al-Hashami Z, Al-Farsi H, Al-mekhlafi AM, Idris MA et al. Genetic diversity of Plasmodium falciparum and distribution of drug resistance haplotypes in Yemen. Malar J 2013; 12: 244.

38. Mendes C, Salgueiro P, Gonzalez V, Berzosa P, Benito A, do Rosário VE et al. Genetic diversity and signatures of selection of drug resistance in Plasmodium populations from both human and mosquito hosts in continental Equatorial Guinea. Malar J 2013; 12: 114. 
39. Li J, Chen J, Xie D, Monte-Nguba SM, Eyi JU, Matesa RA et al. High prevalence of $p f m d r 1 \mathrm{~N} 86 \mathrm{Y}$ and Y184F mutations in Plasmodium falciparum isolates from Bioko Island, Equatorial Guinea.Pathog Glob Health 2014; 108(7): 339-343.

40. Hyde JE. The dihydrofolate reductase-thymidylate synthetase gene in the drug resistance of malaria parasites. Pharmacol Ther 1990; 48: 45-59.

41. Wang P, Read M, Sims PFG, Hyde JE. Sulfadoxine resistance in the human malaria parasite Plasmodium falciparum is determined by mutations in dihydropteroate synthetase and an additional factor associated with folate utilization. Mol Microbiol; 1997; 23: 979-986.

42. Das S, Chakraborty SP, Tripathy S, Hati A, Roy S. Novel quadruple mutations in dihydropteroate synthase genes of Plasmodium falciparum in West Bengal, India. Trop Med Int Health 2012; 17(11): 1329-1334.

43. Foote SJ, Galatis D, Cowman AF. Amino acids in the dihydrofolate reductase-thymidylate synthase gene of Plasmodium falciparum involved in cycloguanil resistance differ from those involved in pyrimethamine resistance. Proc Natl Acad Sci USA 1990; 87(8): 3014-3017.

44. Peterson DS, Di Santi SM, Povoa M, Calvosa VS, Do Rosario VE, Wellems TE. Prevalence of the dihydrofolate reductase Asn-108 mutation as the basis for pyrimethamine-resistant falciparum malaria in the Brazilian Amazon.Am J Trop Med Hyg 1991; 45(4): 492-497.

45. Reeder JC, Rieckmann KH, Genton B, Lorry K, Wines B, Cowman AF. Point mutations in the dihydrofolate reductase and dihydropteroate synthetase genes and in vitro susceptibility to pyrimethamine and cycloguanil of Plasmodium falciparum isolates from Papua New Guinea.Am J Trop Med Hyg 1996; 55(2): 209-213.

46. Edoh D, Mshinda H, Jenkins J, Burger $M$. Pyrimethamine-resistant Plasmodium falciparum parasites among Tanzanian children: a facility-based study using the polymerase chain reaction.Am J Trop Med Hyg 1997; 57(3): 342-347.

47. Parzy D, Doerig C, Pradines B, Rico A, Fusai T, Doury JC. Proguanil resistance in Plasmodium falciparum African isolates: assessment by mutation-specific polymerase chain reaction and in vitro susceptibility testing. Am J Trop Med Hyg 1997; 57(6): 646-650.

48. Basco LK, Ringwald P. Molecular epidemiology of malaria in Yaounde, Cameroon I. Analysis of point mutations in the dihydrofolate reductase-thymidylate synthase gene of Plasmodium falciparum. Am J Trop Med Hyg 1998; 58(3): 369-373.

49. Thaithong S, Chan SW, Songsomboon S, Wilairat $\mathrm{P}$, Seesod N, Sueblinwong T et al. Pyrimethamine resistant mutations in Plasmodium falciparum. Mol Biochem Parasitol 1992; 52(2): 149-157.

50. Carter TE, Warner M, Mulligan CJ, Existe A, Victor YS, Memnon G et al. Evaluation of dihydrofolate reductase and dihydropteroate synthetase genotypes that confer resistance to sulphadoxine-pyrimethamine in Plasmodium falciparum in Haiti. Malar J 2012; 11: 275.

51. Bates SJ, Winstanley PA, Watkins WM, Alloueche A, Bwika J, Happi TC et al. Rare, highly pyrimethamineresistant alleles of the Plasmodium falciparum dihydrofolate reductase gene from 5 African sites. J Infect Dis 2004; 190(10): 1783-1792.

52. Wang P, Lee CS, Bayoumi R, Djimde A, Doumbo $\mathrm{O}$, Swedberg G, Dao LD et al. Resistance to antifolates in Plasmodium falciparum monitored by sequence analysis of dihydropteroate synthetase and dihydrofolate reductase alleles in a large number of field samples of diverse origins. Mol Biochem Parasitol 1997, 89(2): 161-177.

53. Basco LK, Tahar R, Ringwald P. Molecular basis of in vivo resistance to sulfadoxine-pyrimethamine in African adult patients infected with Plasmodium falciparum malaria parasites. Antimicrob Agents Chemother 1998; 42(7): 1811-1814.

54. Jelinek T, Kilian AH, Kabagambe G, von Sonnenburg F. Plasmodium falciparum resistance to sulfadoxine/ pyrimethamine in Uganda: correlation with polymorphisms in the dihydrofolate reductase and dihydropteroate synthetase genes. Am J Trop Med Hyg 1999, 61(3): 463-466.

55. Urdaneta L, Plowe C, Goldman I, Lal AA Point mutations in dihydrofolate reductase and dihydropteroate synthase genes of Plasmodium falciparum isolates from Venezuela. Am J Trop Med Hyg 1999; 61(3): 457-462.

56. Nzila AM, Mberu EK, Sulo J, Dayo H, Winstanley $\mathrm{PA}$, Sibley $\mathrm{CH}$ et al. Towards an understanding of the mechanism of pyrimethamine-sulfadoxine resistance in Plasmodium falciparum: genotyping of dihydrofolate reductase and dihydropteroate synthase of Kenyan parasites. Antimicrob Agents Chemother 2000; 44(4): 991-996.

57. Basco LK, Tahar R, Keundjian A, Ringwald P. Sequence variations in the genes encoding 
dihydropteroate synthase and dihydrofolate reductase and clinical response to sulfadoxine-pyrimethamine in patients with acute uncomplicated falciparum malaria. J Infect Dis 2000; 182(2): 624-628.

58. Happi CT, Gbotosho GO, Folarin OA, Akinboye DO, Yusuf BO, Ebong OO et al. Polymorphisms in Plasmodium falciparum dhfr and dhps genes and age related in vivo sulfadoxine-pyrimethamine resistance in malaria-infected patients from Nigeria. Acta Trop 2005; 95(3): 183-193.

59. Gebru-Woldearegai T, Hailu A, Grobusch MP, Kun JF. Molecular surveillance of mutations in dihydrofolate reductase and dihydropteroate synthase genes of Plasmodium falciparum in Ethiopia. Am J Trop Med Hyg 2005; 73(6): 1131-1134.

60. Mockenhaupt FP, Teun Bousema J, Eggelte TA, Schreiber J, Ehrhardt S, Wassilew N et al. Plasmodium falciparum dhfr but not dhps mutations associated with sulphadoxine-pyrimethamine treatment failure and gametocyte carriage in northern Ghana. Trop Med Int Health 2005; 10(9): 901-908.

61. Hapuarachchi HC, Dayanath MY, Bandara KB, Abeysundara S, Abeyewickreme W, de Silva NR et al. Point mutations in the dihydrofolate reductase and dihydropteroate synthase genes of Plasmodium falciparum and resistance to sulfadoxinepyrimethamine in Sri Lanka. Am J Trop Med Hyg 2006; 74(2): 198-204.

62. Schönfeld M, Barreto Miranda I, Schunk M, Maduhu I, Maboko L, Hoelscher M et al. Molecular surveillance of drug-resistance associated mutations of Plasmodium falciparum in south-west Tanzania. Malar J 2007; 6: 2.

63. Juma DW, Omondi AA, Ingasia L, Opot B, Cheruiyot $\mathrm{A}$, Yeda $\mathrm{R}$ et al. Trends in drug resistance codons in Plasmodium falciparum dihydrofolate reductase and dihydropteroate synthase genes in Kenyan parasites from 2008 to 2012. Malar J 2014; 13: 250.

64. Dorsey G, Dokomajilar C, Kiggundu M, Staedke SG, Kamya MR, Rosenthal PJ. Principal role of dihydropteroate synthase mutations in mediating resistance to sulfadoxine-pyrimethamine in singledrug and combination therapy of uncomplicated malaria in Uganda. Am J Trop Med Hyg 2004; 71(6): $758-763$.

65. Dokomajilar C, Lankoande ZM, Dorsey G, Zongo I, Ouedraogo JB, Rosenthal PJ. Roles of specific Plasmodium falciparum mutations in resistance to amodiaquine and sulfadoxine-pyrimethamine in Burkina Faso. Am J Trop Med Hyg 2006; 75(1): 162-165.
66. Koukouikila-Koussounda F, Bakoua D, Fesser A, Nkombo M, Vouvoungui C, Ntoumi F. High prevalence of sulphadoxine-pyrimethamine resistance-associated mutations in Plasmodium falciparum field isolates from pregnant women in Brazzaville, Republic of Congo. Infect Genet Evol 2015; 33: 32-36.

67. Lucchi NW, Okoth SA, Komino F, Onyona P, Goldman IF, Ljolje D et al. Increasing prevalence of a novel triple-mutant dihydropteroate synthase genotype in Plasmodium falciparum in western Kenya. Antimicrob Agents Chemother 2015; 59(7): 3995-4002.

68. Siame MN, Mharakurwa S, Chipeta J, Thuma P, Michelo C. High prevalence of $d h f r$ and dhps molecular markers in Plasmodium falciparum in pregnant women of Nchelenge district, Northern Zambia. Malar J 2015; 14: 190.

69. Heidari A, Dittrich S, Jelinek $\mathrm{T}$, Kheirandish A, Banihashemi K, Keshavarz H. Genotypes and in vivo resistance of Plasmodium falciparum isolates in an endemic region of Iran. Parasitol Res 2007; 100(3): 589-592.

70. Zakeri S, Farahani MS, Afsharpad M, Salehi M, Raeisi A, Djadid ND. High prevalence of the $437 \mathrm{G}$ mutation associated with sulfadoxine resistance among Plasmodium falciparum clinical isolates from Iran, three years after the introduction of sulfadoxinepyrimethamine. Int J Infect Dis 2010; 14 (Suppl 3): e123-8.

71. Sharma J, Dutta P, Khan SA, Soni M, Dey D, Mahanta J. Genetic polymorphisms associated with sulphadoxine-pyrimethamine drug resistance among Plasmodium falciparum field isolates in malaria endemic areas of Assam. J Postgrad Med 2015; 61(1): 9-14.

72. Das S, Chakraborty SP, Hati A, Roy S. Malaria treatment failure with novel mutation in the Plasmodium falciparum dihydrofolate reductase (pfdhfr) gene in Kolkata, West Bengal, India. Int J Antimicrob Agents 2013; 41(5): 447-451.

73. Lau TY, Sylvi M, William T. Mutational analysis of Plasmodium falciparum dihydrofolate reductase and dihydropteroate synthase genes in the interior division of Sabah, Malaysia. Malar J 2013; 12: 445.

74. Geiger C, Compaore G, Coulibaly B, Sie A, Dittmer $\mathrm{M}$, Sanchez C et al. Substantial increase in mutations in the genes $p f d h f r$ and $p f d h p s$ puts sulphadoxinepyrimethamine-based intermittent preventive treatment for malaria at risk in Burkina Faso. Trop Med Int Health 2014; 19(6): 690-697. 
75. Matondo SI, Temba GS, Kavishe AA, Kauki JS, Kalinga A, van Zwetselaar $M$ et al. High levels of sulphadoxine-pyrimethamine resistance PfdhfrPfdhps quintuple mutations: a cross sectional survey of six regions in Tanzania. Malar J 2014; 13: 152.

76. Basuki S, Fitriah, Riyanto S, Budiono, Dachlan YP, Uemura H. Two novel mutations of pfdhps K540T and $\mathrm{I} 588 \mathrm{~F}$, affecting sulphadoxine-pyrimethamineresistant response in uncomplicated falciparum malaria at Banjar district, South Kalimantan Province, Indonesia. Malar J 2014; 13: 135.

77. Awab GR, Pukrittayakamee S, Jamornthanyawat N, Yamin F, Dondorp AM, Day NP et al. Prevalence of antifolate resistance mutations in Plasmodium falciparum isolates in Afghanistan. Malar J 2013; 12: 96.

78. Imwong $\mathrm{M}$, Pukrittakayamee $\mathrm{S}$, Looareesuwan $\mathrm{S}$, Pasvol G, Poirreiz J, White NJ et al. Association of genetic mutations in Plasmodium vivax dhfr with resistance to sulfadoxine-pyrimethamine: geographical and clinical correlates. Antimicrob Agents Chemother 2001; 45 (11): 3122-3127.

79. Korsinczky M, Fischer K, Chen N, Baker J, Rieckmann $\mathrm{K}$, Cheng Q. Sulfadoxine resistance in Plasmodium vivax is associated with a specific amino acid in dihydropteroate synthase at the putative sulfadoxinebinding site. Antimicrob Agents Chemother 2004; 48(6): 2214-2222.

80. Lu F, Lim CS, Nam DH, Kim K, Lin K, Kim TS et al. Mutations in the antifolate-resistance-associated genes dihydrofolate reductase and dihydropteroate synthase in Plasmodium vivax isolates from malaria-endemic countries. Am J Trop Med Hyg 2010; 83(3): 474-479.

81. Miao M, Yang Z, Cui L, Ahlum J, Huang Y, Cui L. Different allele prevalence in the dihydrofolate reductase and dihydropteroate synthase genes in Plasmodium vivax populations from China. Am J Trop Med Hyg 2010; 83(6): 1206-1211.

82. Pirahmadi S, Talha BA, Nour BY, Zakeri S. Prevalence of mutations in the antifolates resistance-associated genes (dhfr and dhps) in Plasmodium vivax parasites from Eastern and Central Sudan. Infect Genet Evol 2014; 26: 153-139.

83. Huang F, Zhou S, Zhang S, Li W, Zhang H. Monitoring resistance of Plasmdium vivax: point mutations in dihydrofolate reductase gene in isolates from Central China. Parasit Vectors 2011; 4: 80.

84. Chehuan YF, Costa MR, Costa JS, Alecrim MG, Nogueira $\mathrm{F}$, Silveira $\mathrm{H}$ et al. In vitro chloroquine resistance for Plasmodium vivax isolates from the Western Brazilian Amazon. Malar J 2013; 12: 226.

85. Peel SA, Bright P, Yount B, Handy J, Baric RS. A strong association between mefloquine and halofantrine resistance and amplification, overexpression, and mutation in the P-glycoprotein gene homolog $(p f m d r)$ of Plasmodium falciparum in vitro. Am J Trop Med Hyg 1994; 51(5): 648-658.

86. Price RN, Cassar C, Brockman A, Duraisingh M, van Vugt M, White NJ et al. The $p f m d r 1$ gene is associated with a multidrug-resistant phenotype in Plasmodium falciparum from the western border of Thailand. Antimicrob Agents Chemother 1999; 43(12): 29432949.

87. Duraisingh MT, Cowman AF. Contribution of the pfmdrl gene to antimalarial drug-resistance. Acta Trop 2005; 94(3): 181-190.

88. Sidhu AB, Valderramos SG, Fidock DA. pfmdrl mutations contribute to quinine resistance and enhance mefloquine and artemisinin sensitivity in Plasmodium falciparum. Mol Microbiol 2005; 57(4): 913-926.

89. Gupta B, Xu S, Wang Z, Sun L, Miao J, Cui L et al. Plasmodium falciparum multidrug resistance protein 1 (pfmrp 1 ) gene and its association with in vitro drug susceptibility of parasite isolates from northeast Myanmar. J Antimicrob Chemother 2014; 69(8): 2110-2117.

90. Das S, Chakraborty SP, Hati AK, Roy S. Association between prevalence of chloroquine resistance and unusual mutation in $p f m d r 1$ and pfcrt genes in India. Am J Trop Med Hyg 2013b, 88(5): 828-834.

91. Flüeck TP, Jelinek T, Kilian AH, Adagu IS, Kabagambe $\mathrm{G}$, Sonnenburg $\mathrm{F}$ et al. Correlation of in vivo resistance to chloroquine and allelic polymorphisms in Plasmodium falciparum isolates from Uganda. Trop Med Int Health 2000; 5(3): 174-178.

92. Mawili-Mboumba DP, Kun JF, Lell B, Kremsner PG, Ntoumi F. Pfmdr1 alleles and response to ultralowdose mefloquine treatment in Gabonese patients. Antimicrob Agents Chemother 2002; 46(1): 166-170.

93. Pickard AL, Wongsrichanalai C, Purfield A, Kamwendo D, Emery K, Zalewski C et al. Resistance to antimalarials in Southeast Asia and genetic polymorphisms in pfmdr1.Antimicrob Agents Chemother 2003; 47(8): 2418-2423.

94. Congpuong $\mathrm{K}$, Na Bangchang $\mathrm{K}$, Mungthin M, Bualombai P, Wernsdorfer WH. Molecular epidemiology of drug resistance markers of 
Plasmodium falciparum malaria in Thailand. Trop Med Int Health 2005; 10(8): 717-722.

95. Jalousian F, Dalimi A, Samiee SM, Ghaffarifar F, Soleymanloo F, Naghizadeh R. Mutation in pfmdrl gene in chloroquine-resistant Plasmodium falciparum isolates, Southeast Iran. Int J Infect Dis 2008; 12(6): 630-634.

96. Inoue J, Lopes D, do Rosário V, Machado M, Hristov $\mathrm{AD}$, Lima GF et al. Analysis of polymorphisms in Plasmodium falciparum genes related to drug resistance: a survey over four decades under different treatment policies in Brazil. Malar J 2014; 13: 372.

97. Duraisingh MT, Jones P, Sambou I, von Seidlein L, Pinder M, Warhurst DC. The tyrosine- 86 allele of the $p f m d r 1$ gene of Plasmodium falciparum is associated with increased sensitivity to the anti-malarials mefloquine and artemisinin. Mol Biochem Parasitol 2000; 108(1): 13-23.

98. Barnadas C, Ratsimbasoa A, Tichit M, Bouchier C, Jahevitra M, Picot S, Ménard D. Plasmodium vivax resistance to chloroquine in Madagascar: clinical efficacy and polymorphisms in pvmdr1 and pvcrt-o genes. Antimicrob Agents Chemother 2008; 52(12): 4233-4240.

99. Shalini S, Chaudhuri S, Sutton PL, Mishra N, Srivastava N, David JK et al. Chloroquine efficacy studies confirm drug susceptibility of Plasmodium vivax in Chennai, India. Malar J; 2014; 13: 129.

100. Severini C, Menegon M, Sannella AR, Paglia MG, Narciso P, Matteelli A et al. Prevalence of $p f c r t$ point mutations and level of chloroquine resistance in Plasmodium falciparum isolates from Africa. Infect Genet Evol 2006; 6(4): 262-268.

101.Abruquah H, Bio F, Tay S, Lawson B. Resistancemediating polymorphisms of Plasmodium falciparum among isolates from children with severe malaria in kumasi, Ghana. Ghana Med J 2010; 44(2): 52-58.

102.Bla BK, Yavo W, Trébissou J, Kipré RG, Yapi FH, N'guessan JD et al. Polymorphisms of the Pfatpase6 and Pfcrt gene and their relationship with the in vitro susceptibility to dihydroartemisinin and chloroquine of Plasmodium falciparum isolates from Abobo, Côte d'Ivoire. Ann Parasitol 2014; 60(4): 259-266.

103.Bin Dajem SM, Al-Qahtani A. Analysis of gene mutations involved in chloroquine resistance in Plasmodium falciparum parasites isolated from patients in the southwest of Saudi Arabia. Ann Saudi Med 2010; 30(3): 187-192.
104.Al-Mekhlafi AM, Mahdy MA, Al-Mekhlafi HM, Azazy AA, Fong MY. High frequency of Plasmodium falciparum chloroquine resistance marker (pfcrt T76 mutation) in Yemen: an urgent need to re-examine malaria drug policy. Parasit Vectors. 2011; 4: 94.

105. Chaijaroenkul W, Ward SA, Mungthin M, Johnson D, Owen A, Bray PG et al. Sequence and gene expression of chloroquine resistance transporter ( $p f c r t$ ) in the association of in vitro drugs resistance of Plasmodium falciparum. Malar J 2011; 10: 42.

106.Atroosh WM, Al-Mekhlafi HM, Mahdy MA, Surin J. The detection of $p f c r t$ and $p f m d r 1$ point mutations as molecular markers of chloroquine drug resistance, Pahang, Malaysia. Malar J 2012; 11: 251.

107.Abdul-Ghani R, Farag HF, Allam AF, Shawky SM, Al-Mekhlafi AM. Mutant Plasmodium falciparum chloroquine resistance transporter in Hodeidah, Yemen: association with parasitologic indices and treatment-seeking behaviors. Acta Trop 2013; 128(3): 473-478.

108. Schneider AG, Premji Z, Felger I, Smith T, Abdulla S, Beck HP et al. A point mutation in codon 76 of pfcrt of $P$. falciparum is positively selected for by chloroquine treatment in Tanzania.Infect Genet Evol 2002; 1(3): 183-189.

109.Beshir K, Sutherland CJ, Merinopoulos I, Durrani N, Leslie T, Rowland $\mathrm{M}$ et al. Amodiaquine resistance in Plasmodium falciparum malaria in Afghanistan is associated with the $p f c r t$ SVMNT allele at codons 72 to 76.575. Antimicrob Agents Chemother 2010; 54(9): 3714-3716.

110. Mekonnen SK, Aseffa A, Berhe N, Teklehaymanot T, Clouse RM, Gebru T et al. Return of chloroquinesensitive Plasmodium falciparum parasites and emergence of chloroquine-resistant Plasmodium vivax in Ethiopia. Malar J 2014; 13: 244.

111. Bamaga OA, Mahdy MA, Lim YA. Survey of chloroquine-resistant mutations in the Plasmodium falciparum pfcrt and pfmdr1 genes in Hadhramout, Yemen. Acta Trop 2015; 149: 59-63.

112. Happi CT, Gbotosho GO, Folarin OA, Bolaji OM, Sowunmi A, Kyle DE et al. Association between mutations in Plasmodium falciparum chloroquine resistance transporter and $P$. falciparum multidrug resistance 1 genes and in vivo amodiaquine resistance in P. falciparum malaria-infected children in Nigeria. Am J Trop Med Hyg 2006; 75(1): 155-161.

113. Echeverry DF, Holmgren G, Murillo C, Higuita JC, Björkman A, Gil JP, Osorio L. Short report: 
polymorphisms in the pfcrt and pfmdrl genes of Plasmodium falciparum and in vitro susceptibility to amodiaquine and desethylamodiaquine. Am J Trop Med Hyg 2007; 77(6): 1034-1038.

114. Folarin OA, Bustamante C, Gbotosho GO, Sowunmi $\mathrm{A}$, Zalis MG, Oduola AM et al. In vitro amodiaquine resistance and its association with mutations in $p f c r t$ and $p f m d r 1$ genes of Plasmodium falciparum isolates from Nigeria. Acta Trop 2011; 120(3): 224-30.

115. Gama BE, Pereira-Carvalho GA, Lutucuta Kosi FJ, Almeida de Oliveira NK, Fortes F, Rosenthal PJ et al. Plasmodium falciparum isolates from Angola show the StctVMNT haplotype in the pfcrt gene. Malar J 2010; 9: 174.

116. Sutar SK, Gupta B, Ranjit M, Kar SK, Das A. Sequence analysis of coding DNA fragments of $p f c r t$ and $p f m d r 1$ genes in Plasmodium falciparum isolates from Odisha, India. Mem Inst Oswaldo Cruz 2011; 106(1): 78-84.

117. Goswami D, Dhiman S, Rabha B, Kumar D, Baruah I, Veer V et al. High prevalence of $p f c r t \mathrm{~K} 76 \mathrm{~T}$ and $m d r 1$ N86Y mutations in Sonitpur district of Assam, India. J Parasit Dis 2014; 38(3): 250-254.

118. Shrivastava SK, Gupta RK, Mahanta J, Dubey ML. Correlation of molecular markers, pfmdr1-N86Y and pfcrt-K76T, with in vitro chloroquine resistant Plasmodium falciparum, isolated in the malaria endemic states of Assam and Arunachal Pradesh, Northeast India. PLoS One 2014; 9(8): e103848.

119. Setthaudom C, Tan-ariya P, Sitthichot N, Khositnithikul $\mathrm{R}$, Suwandittakul N, Leelayoova S et al. Role of Plasmodium falciparum chloroquine resistance transporter and multidrug resistance 1 genes on in vitro chloroquine resistance in isolates of Plasmodium falciparum from Thailand. Am J Trop Med Hyg 2011; 85(4): 606-611.

120.Hatabu T, Iwagami M, Kawazu S, Taguchi N, Escueta $\mathrm{AD}$, Villacorte EA et al. Association of molecular markers in Plasmodium falciparum crt and $m d r 1$ with in vitro chloroquine resistance: a Philippine study. Parasitol Int 2009; 58(2): 166-170.

121. Briolant S, Bogreau H, Gil M, Bouchiba H, Baret $\mathrm{E}$, Amalvict $\mathrm{R}$ et al. The $\mathrm{F} 423 \mathrm{Y}$ mutation in the pfmdr2 gene and mutations N51I, C59R, and S108N in the pfdhfr gene are independently associated with pyrimethamine resistance in Plasmodium falciparum isolates.Antimicrob Agents Chemother 2012; 56(5): 2750-2752.

122. Orjuela-Sánchez P, de Santana Filho FS, MachadoLima A, Chehuan YF, Costa MR, Alecrim MD et al.
Analysis of single-nucleotide polymorphisms in the crt-o and mdrl genes of Plasmodium vivax among chloroquine-resistant isolates from the Brazilian Amazon region.Antimicrob Agents Chemother 2009; 53(8): 3561-3564.

123. Golassa L, Erko B, Baliraine FN, Aseffa A, Swedberg G. Polymorphisms in chloroquine resistanceassociated genes in Plasmodium vivax in Ethiopia. Malar J 2015; 14: 164.

124. Syafruddin D, Siregar JE, Marzuki S. Mutations in the cytochrome $\mathrm{b}$ gene of Plasmodium berghei conferring resistance to atovaquone. Mol Biochem Parasitol 1999; 104(2): 185-94.

125.Korsinczky M, Chen N, Kotecka B, Saul A, Rieckmann K, Cheng Q. Mutations in Plasmodium falciparum cytochrome $\mathrm{b}$ that are associated with atovaquone resistance are located at a putative drug-binding site Antimicrob Agents Chemother 2000; 44: 2100-2108.

126.Fivelman Q, Butcher G, Adagu I, Warhurst D, Pasvol G. Malarone treatment failure and in vitro confirmation of resistance of Plasmodium falciparum isolate from Lagos, Nigeria: Case report. Malar J 2002; 1: 1.

127.Siregar JE, Kurisu G, Kobayashi T, Matsuzaki M, Sakamoto K, Mi-ichi F et al. Direct evidence for the atovaquone action on the Plasmodium cytochrome bc1 complex. Parasitol Int 2015; 64(3): 295-300.

128.Pimentel S, Nogueira F, Benchimol C, Quinhentos V, Bom J, Varandas L et al. Detection of atovaquoneproguanil resistance conferring mutations in Plasmodium falciparum cytochrome b gene in Luanda, Angola. Malar J 2006; 5: 30.

129. Basco LK, Ringwald P. Chloroquine resistance in Plasmodium falciparum and polymorphism of the CG2 gene. J Infect Dis 1999; 180(6): 1979-1986.

130.Basco LK, Ringwald P. Molecular epidemiology of malaria in Yaounde, Cameroon V. analysis of the omega repetitive region of the Plasmodium falciparum $c g 2$ gene and chloroquine resistance. Am J Trop Med Hyg 1999: 61(5): 807-813.

131. Okombo J, Kiara SM, Rono J, Mwai L, Pole L, Ohuma $\mathrm{E}$ et al. In vitro activities of quinine and other antimalarials and pfnhe polymorphisms in Plasmodium isolates from Kenya. Antimicrob Agents Chemother 2010; 54(8): 3302-3307.

132.Meng H, Zhang R, Yang H, Fan Q, Su X, Miao J et al. In vitro sensitivity of Plasmodium falciparum clinical isolates from the China-Myanmar border area to quinine and association with polymorphism in the 
$\mathrm{Na}+/ \mathrm{H}+$ exchanger.Antimicrob Agents Chemother 2010; 54(10): 4306-4313.

133. Sinou V, Quang le H, Pelleau S, Huong VN, Huong NT, Tai le $\mathrm{M}$ et al. Polymorphism of Plasmodium falciparum $\mathrm{Na}(+) / \mathrm{H}(+)$ exchanger is indicative of a low in vitro quinine susceptibility in isolates from Viet Nam. Malar J2011; 10: 164.

134.Poyomtip T, Suwandittakul N, Sitthichot N, Khositnithikul R, Tan-ariya P, Mungthin M. Polymorphisms of the $p f m d r 1$ but not the $p f n h e 1$ gene is associated with in vitro quinine sensitivity in Thai isolates of Plasmodium falciparum. Malar J 2012; 11: 7 .

135.Phompradit P, Wisedpanichkij R, Muhamad P, Chaijaroenkul W, Na-Bangchang K.Molecular analysis of $p f a t p 6$ and $p f m d r 1$ polymorphisms and their association with in vitro sensitivity in Plasmodium falciparum isolates from the Thai-Myanmar border. Acta Trop 2011; 120(1-2): 130-135.

136. Veiga MI, Osório NS, Ferreira PE, Franzén O, Dahlstrom S, Lum JK et al. Complex polymorphisms in the Plasmodium falciparum multidrug resistance protein 2 gene and its contribution to antimalarial response. Antimicrob Agents Chemother 2014; 58(12): 7390-7397.

137. Afonso A, Hunt P, Cheesman S, Alves AC, Cunha CV, do Rosário V, Cravo P. Malaria parasites can develop stable resistance to artemisinin but lack mutations in candidate genes atp6 (encoding the sarcoplasmic and endoplasmic reticulum $\mathrm{Ca} 2+\mathrm{ATPase}), t c t p, m d r 1$, and cg10. Antimicrob Agents Chemother 2006; 50(2): 480-489.

138. Noedl H, Se Y, Schaecher K, Smith BL, Socheat D, Fukuda MM. Evidence of artemisinin-resistant malaria in western Cambodia. N Engl J Med; 2008; 359: 2619-2620.

139. Phyo AP, Nkhoma S, Stepniewska K, Ashley EA, Nair S, McGready R et al. Emergence of artemisininresistant malaria on the western border of Thailand: a longitudinal study. Lancet 2012; 379: 1960-1966.

140.Kyaw MP, Nyunt MH, Chit K, Aye MM, Aye KH, Aye MM et al. Reduced susceptibility of Plasmodium falciparum to artesunate in southern Myanmar. PLoS One 2013; 8: e57689.

141.Imwong M, Dondorp AM, Nosten F, Yi P, Mungthin $\mathrm{M}$, Hanchana $\mathrm{S}$ et al. Exploring the contribution of candidate genes to artemisinin resistance in Plasmodium falciparum. Antimicrob Agents Chemother 2010; 54(7): 2886-2892.
142.Adhin MR, Labadie-Bracho M, Vreden SG. Status of potential pfatp 6 molecular markers for artemisinin resistance in Suriname. Malar J2012; 11: 322.

143. Cui L, Wang Z, Jiang H, Parker D, Wang H, Su XZ et al. Lack of association of the $\mathrm{S} 769 \mathrm{~N}$ mutation in Plasmodium falciparum SERCA (pfatp6) with resistance to artemisinins. Antimicrob Agents Chemother 2012; 56(5): 2546-2552.

144.Huang F, Tang L, Yang H, Zhou S, Sun X, Liu H. Therapeutic efficacy of artesunate in the treatment of uncomplicated Plasmodium falciparum malaria and anti-malarial, drug-resistance marker polymorphisms in populations near the China-Myanmar border. Malar J 2012; 11: 278.

145.Zakeri S, Hemati S, Pirahmadi S, Afsharpad M, Raeisi A, Djadid ND. Molecular assessment of atpase6 mutations associated with artemisinin resistance among unexposed and exposed Plasmodium falciparum clinical isolates to artemisinin-based combination therapy. Malar J 2012; 11: 373.

146. Miao M, Wang Z, Yang Z, Yuan L, Parker DM, Putaporntip $\mathrm{C}$ et al. Genetic diversity and lack of artemisinin selection signature on the Plasmodium falciparum ATP6 in the Greater Mekong Subregion. PLoS One 2013; 8(3): e59192.

147. Chilongola J, Ndaro A, Tarimo H, Shedrack T, Barthazary S, Kaaya R et al. Occurrence of pfatpase6 single nucleotide polymorphisms associated with artemisinin resistance among field isolates of Plasmodium falciparum in North-Eastern Tanzania. Malar Res Treat 2015; 2015: 279028.

148.Pirahmadi S, Zakeri S, Afsharpad M, Djadid ND Mutation analysis in $p f m d r 1$ and $p f m r p 1$ as potential candidate genes for artemisinin resistance in Plasmodium falciparum clinical isolates 4 years after implementation of artemisinin combination therapy in Iran. Infect Genet Evol 2013; 14: 327-334.

149. Ibrahim ML, Khim N, Adam HH, Ariey F, Duchemin JB. Polymorphism of PfATPase in Niger: detection of three new point mutations. Malar J 2009; 8: 28.

150.Menegon M, Talha AA, Severini C, Elbushra SM, Mohamedani AA, Malik EM et al. Frequency distribution of antimalarial drug resistance alleles among Plasmodium falciparum isolates from Gezira State, central Sudan, and Gedarif State, eastern Sudan. Am J Trop Med Hyg 2010; 83(2): 250-257.

151.Conrad MD, Bigira V, Kapisi J, Muhindo M, Kamya MR, Havlir DV et al. Polymorphisms in K13 and falcipain-2 associated with artemisinin resistance are 
not prevalent in Plasmodium falciparum isolated from Ugandan children. PLoS One 2014; 9(8): e105690.

152. Mok S, Imwong M, Mackinnon MJ, Sim J, Ramadoss $\mathrm{R}$, Yi $\mathrm{P}$ et al. Artemisinin resistance in Plasmodium falciparum is associated with an altered temporal pattern of transcription. BMC Genomics 2011; 12: 391.

153. Witkowski B, Lelievre J, Barragan MJ, Laurent V, Su $\mathrm{XZ}$, Berry A et al. Increased tolerance to artemisinin in Plasmodium falciparum is mediated by a quiescence mechanism. Antimicrob Agents Chemother 2010; 54: 1872-1877.

154.Ashley EA, Dhorda M, Fairhurst RM, Amaratunga C, Lim P, Suon S et al. Spread of artemisinin resistance in Plasmodium falciparum malaria. N Engl J Med 2014; 371(5): 411-423.

155. Mohon AN, Alam MS, Bayih AG, Folefoc A, Shahinas $\mathrm{D}$, Haque R et al. Mutations in Plasmodium falciparum K13 propeller gene from Bangladesh (2009-2013). Malar J 2014; 13: 431.

156. Huang F, Takala-Harrison S, Jacob CG, Liu H, Sun X, Yang $\mathrm{H}$ et al. A single mutation in K13 predominates in Southern China and is associated with delayed clearance of Plasmodium falciparum following artemisinin treatment. J Infect Dis 2015; 212(10): 1629-1635.

157. Nyunt MH, Hlaing T, Oo HW, Tin-Oo LL, Phway HP, Wang B et al. Molecular assessment of artemisinin resistance markers, polymorphisms in the $k 13$ propeller, and a multidrug-resistance gene in the eastern and western border areas of Myanmar. Clin Infect Dis 2015; 60(8): 1208-1215.

158. Wang Z, Shrestha S, Li X, Miao J, Yuan L, Cabrera M et al. Prevalence of K13-propeller polymorphisms in Plasmodium falciparum from China-Myanmar border in 2007-2012. Malar J 2015; 14: 168.

159. Wang Z, Wang Y, Cabrera M, Zhang Y, Gupta B, Wu $\mathrm{Y}$ et al. Artemisinin resistance at the China-Myanmar border and association with mutations in the K13propeller gene. Antimicrob Agents Chemother 2015; 59(11): 6952-6959.

160. Torrentino-Madamet M, Fall B, Benoit N, Camara C, Amalvict R, Fall $\mathrm{M}$ et al. Limited polymorphisms in $k 13$ gene in Plasmodium falciparum isolates from Dakar, Senegal in 2012-2013. Malar J 2014; 13: 472.

161. Ouattara A, Kone A, Adams M, Fofana B, Maiga AW, Hampton $\mathrm{S}$ et al. Polymorphisms in the K13propeller gene in artemisinin-susceptible Plasmodium falciparum parasites from Bougoula-Hameau and
Bandiagara, Mali. Am J Trop Med Hyg 2015; 92(6): 1202-1206.

162.Taylor SM, Parobek CM, DeConti DK, Kayentao $\mathrm{K}$, Coulibaly SO, Greenwood BM et al. Absence of putative artemisinin resistance mutations among Plasmodium falciparum in Sub-Saharan Africa: a molecular epidemiologic study. J Infect Dis; 2015; 211(5): 680-688

163. Brindley PJ, Lewis FA, McCutchan TF, Bueding E, Sher A. A genomic change associated with the development of resistance to hycanthone in Schistosoma mansoni. Mol Biochem Parasitol 1989; 36(3): 243-252.

164.Brindley PJ, Heath S, Waters AP, McCutchan TF, Sher A. Characterization of a programmed alteration in an $18 \mathrm{~S}$ ribosomal gene that accompanies the experimental induction of drug resistance in Schistosoma mansoni. Proc Natl Acad Sci USA 1991; 88(17): 7754-7758.

165.Pica-Mattoccia L, Dias LC, Moroni R, Cioli D. Schistosoma mansoni: genetic complementation analysis shows that two independent hycanthone/ oxamniquine-resistant strains are mutated in the same gene. Exp Parasitol 1993; 77(4): 445-449.

166.Upcroft J, Mitchell R, Chen N, Upcroft P. Albendazole resistance in Giardia is correlated with cytoskeletal changes but not with a mutation at amino acid 200 in beta-tubulin. Microb Drug Resist 1996; 2(3): 303-308.

167.Jiménez-Cardoso E, Eligio-García L, Cortés-Campos A, Flores-Luna A, Valencia-Mayoral P, LozadaChávez I. Changes in beta-giardin sequence of Giardia intestinalis sensitive and resistant to albendazole strains. Parasitol Res 2009; 105(1): 25-33.

168. Orozco E, López C, Gómez C, Pérez DG, Marchat $\mathrm{L}$, Bañuelos $\mathrm{C}$ et al.. Multidrug resistance in the protozoan parasite Entamoeba histolytica. Parasitol Int 2002; 51(4): 353-359.

169.Upcroft P, Upcroft JA. Drug targets and mechanisms of resistance in the anaerobic protozoa. Clin Microbiol Rev 2001; 14: 150-164.

170. Crowell AL, Sanders-Lewis KA, Secor WE. In vitro metronidazole and tinidazole activities against metronidazole-resistant strains of Trichomonas vaginalis. Antimicrob Agents Chemother 2003; 47: 1407-1409.

171.Müller J, Ley S, Felger I, Hemphill A, Müller N. Identification of differentially expressed genes in a Giardia lamblia WB C6 clone resistant to nitazoxanide and metronidazole. J Antimicrob Chemother 2008; 62 . $72-82$. 
172.Quon DV, d'Oliveira CE, Johnson PJ. Reduced transcription of the ferredoxin gene in metronidazoleresistant Trichomonas vaginalis. Proc Natl Acad Sci USA 1992, 89(10): 4402-4406.

173. Snipes LJ, Gamard PM, Narcisi EM, Beard CB, Lehmann T, Secor WE.Molecular epidemiology of metronidazole resistance in a population of Trichomonas vaginalis clinical isolates. J Clin Microbiol 2000; 38(8): 3004-3009.

174.Pal D, Banerjee S, Cui J, Schwartz A, Ghosh SK, Samuelson J. Giardia, Entamoeba, and Trichomonas enzymes activate metronidazole (nitroreductases) and inactivate metronidazole (nitroimidazole reductases). Antimicrob Agents Chemother 2009; 53(2): 458-464.

175.Kazemi F, Hooshyar H, Zareikar B, Bandehpour M, Arbabi M, Talari S et al. Study on ITS1 gene of Iranian Trichomonas vaginalis by molecular methods.Iran J Parasitol 2010; 5(4): 9-14.

176.Heidari S, Bandehpour M, Seyyed-Tabaei SJ, Valadkhani Z, Haghighi A, Abadi A et al. Ferredoxin genemutation in Iranian Trichomonas vaginalis isolates. Iran J Parasitol 2013; 8(3): 402-407.

177.Matovu E, Geiser F, Schneider V, Mäser P, Enyaru JC, Kaminsky R et al. Genetic variants of the TbAT1 adenosine transporter from African trypanosomes in relapse infections following melarsoprol therapy. Mol Biochem Parasitol 2001; 117(1): 73-81.

178.Matovu E, Stewart ML, Geiser F, Brun R, Mäser $\mathrm{P}$, Wallace LJ et al. Mechanisms of arsenical and diamidine uptake and resistance in Trypanosoma brucei. Eukaryot Cell 2003; 2(5): 1003-1008.

179. Maina N, Maina KJ, Mäser P, Brun R. Genotypic and phenotypic characterization of Trypanosoma brucei gambiense isolates from Ibba, South Sudan, an area of high melarsoprol treatment failure rate. Acta Trop 2007; 104(2-3): 84-90.

180.Chitanga S, Marcotty T, Namangala B, Van den Bossche P, Van Den Abbeele J, Delespaux V. High prevalence of drug resistance in animal trypanosomes without a history of drug exposure. PLoS Negl Trop Dis 2011; 5(12): e1454

181. Graf FE, Ludin P, Wenzler T, Kaiser M, Brun R, Pyana $\mathrm{PP}$ et al. Aquaporin 2 mutations in Trypanosoma brucei gambiense field isolates correlate with decreased susceptibility to pentamidine and melarsoprol. PLoS Negl Trop Dis 2013; 7(10): e2475.

182.Baker N, Hamilton G, Wilkes JM, Hutchinson S, Barrett MP, Horn D. Vacuolar ATPase depletion affects mitochondrial ATPase function, kinetoplast dependency, and drug sensitivity in trypanosomes. Proc Natl Acad Sci USA 2015; 112(29): 9112-9117.

183. McFadden DC, Tomavo S, Berry EA and Boothroyd JC. Characterization of cytochrome b from Toxoplasma gondii and $\mathrm{Q}(\mathrm{o})$ domain mutations as a mechanism of atovaquone-resistance. Mol Biochem Parasitol 2000; 108(1): 1-12.

184. Reynolds MG, Oh J, Roos DS. In vitro generation of novel pyrimethamine resistance mutations in the Toxoplasma gondii dihydrofolate reductase. Antimicrob Agents Chemother 2001; 45(4): 12711277.

185. Aspinall TV, Joynson DH, Guy E, Hyde JE, Sims PF. The molecular basis of sulfonamide resistance in Toxoplasma gondii and implications for the clinical management of toxoplasmosis. J Infect Dis 2002; 185(11): 1637-1643.

186. Meneceur P, Bouldouyre MA, Aubert D, Villena I, Menotti J, Sauvage V et al. In vitro susceptibility of various genotypic strains of Toxoplasma gondii to pyrimethamine, sulfadiazine, and atovaquone. Antimicrob Agents Chemother 2008; 52(4): 1269-1277.

187.Doliwa C, Escotte-Binet S, Aubert D, Sauvage V, Velard F, Schmid A et al. Sulfadiazine resistance in Toxoplasma gondii: no involvement of overexpression or polymorphisms in genes of therapeutic targets and ABC transporters. Parasite 2013; 20: 19.

188. Bello AR, Nare B, Freedman D, Hardy L, Beverley SM. PTR1: a reductase mediating salvage of oxidized pteridines and methotrexate resistance in the protozoan parasite Leishmania major. Proc Natl Acad Sci USA 1994; 91(24): 11442-11446.

189. Schnaufer A, Sbicego S, Blum B. Antimycin A resistance in a mutant Leishmania tarentolae strain is correlated to a point mutation in the mitochondrial apocytochrome b gene. Curr Genet 2000; 37(4): 234-241.

190.Anacleto C, Abdo MC, Ferreira AV, Murta SM, Romanha AJ, Fernandes AP et al. Structural and functional analysis of an amplification containing a PGPA gene in a glucantime-resistant Leishmania (Viannia) guyanensis cell line. Parasitol Res 2003; 90(2): 110-118.

191.Roy A, BoseDasgupta S, Ganguly A, Jaisankar P, Majumder HK. Topoisomerase I gene mutations at F270 in the large subunit and N184 in the small subunit contribute to the resistance mechanism of the 
unicellular parasite Leishmania donovani towards 3, 3'-diindolylmethane. Antimicrob Agents Chemother 2009; 53(6): 2589-2598.

192. Torres DC, Ribeiro-Alves M, Romero GA, Dávila AM, Cupolillo E. Assessment of drug resistance related genes as candidate markers for treatment outcome prediction of cutaneous leishmaniasis in Brazil. Acta Trop 2013; 126(2): 132-141.

193. Monte-Neto R, Laffitte MC, Leprohon P, Reis $\mathrm{P}$, Frézard F, Ouellette M. Intrachromosomal amplification, locus deletion and point mutation in the aquaglyceroporin AQP1 gene in antimony resistant Leishmania (Viannia) guyanensis. PLoS Negl Trop Dis 2015; 9(2): e0003476.

194. Ritt JF, Raymond F, Leprohon P, Légaré D, Corbeil J, Ouellette M. Gene amplification and point mutations in pyrimidine metabolic genes in 5-fluorouracil resistant Leishmania infantum. PLoS Negl Trop Dis 2013; 7(11): e2564.

195.Fong D, Chan MM, Rodriguez R, Gately LJ, Berman JD, Grogl M. Paromomycin resistance in Leishmania tropica: lack of correlation with mutation in the small subunit ribosomal RNA gene. Am J Trop Med Hyg 1994; 51(6): 758-766.

196. Bhandari V, Kulshrestha A, Deep DK, Stark O, Prajapati VK, Ramesh V et al. Drug susceptibility in Leishmania isolates following miltefosine treatment in cases of visceral leishmaniasis and post kala-azar dermal leishmaniasis. PLoS Negl Trop Dis 2012; 6(5): e1657.

197. Matsuu A, Miyamoto K, Ikadai H, Okano S, Higuchi S. Short report: cloning of the Babesia gibsoni cytochrome B gene and isolation of three single nucleotide polymorphisms from parasites present after atovaquone treatment. Am J Trop Med Hyg 2006; 74(4): 593-597.

198. Schwenkenbecher JM, Kaplan RM. Real-time PCR assays for monitoring benzimidazole resistanceassociated mutations in Ancylostoma caninum. Exp Parasitol 2009; 122(1): 6-10.

199.Pan D, Das S, Bera AK, Bandyopadhyay S, Bandyopadhyay S, De $\mathrm{S}$ et al. Molecular and biochemical mining of heat-shock and 14-3-3 proteins in drug-induced protoscolices of Echinococcus granulosus and the detection of a candidate gene for anthelmintic resistance. J Helminthol 2011; 85(2): 196-203.

200.Murta SM, dos Santos WG, Anacleto C, Nirdé $\mathrm{P}$, Moreira ES, Romanha AJ. Drug resistance in
Trypanosoma cruzi is not associated with amplification or overexpression of P-glycoprotein (PGP) genes. Mol Biochem Parasitol 2001; 117(2): 223-228.

201.Mejia AM, Hall BS, Taylor MC, Gómez-Palacio A, Wilkinson SR, Triana-Chávez O et al. Benznidazoleresistance in Trypanosoma cruzi is a readily acquired trait that can arise independently in a single population. J Infect Dis 2012; 206(2): 220-228.

202.Peyron F, Eudes N, de Monbrison F, Wallon M, Picot S. Fitness of Toxoplasma gondii is not related to DHFR single-nucleotide polymorphism during congenital toxoplasmosis. Int J Parasitol 2004; 34(10): 1169-1175.

203.Frankel MB, Mordue DG, Knoll LJ. Discovery of parasite virulence genes reveals a unique regulator of chromosome condensation 1 ortholog critical for efficient nuclear trafficking. Proc Natl Acad Sci USA 2007; 104(24): 10181-10186.

204.Mordue DG, Scott-Weathers CF, Tobin CM, Knoll LJ. A patatin-like protein protects Toxoplasma gondii from degradation in activated macrophages. Mol Microbiol 2007; 63(2): 482-496.

205.Craver MP, Rooney PJ, Knoll LJ. Isolation of Toxoplasma gondii development mutants identifies a potential proteophosphogylcan that enhances cyst wall formation. Mol Biochem Parasitol 2010; 169(2): 120-123.

206.Payne TM, Lund PJ and Knoll LJ. A transmembrane domain containing pellicle protein of Toxoplasma gondii enhances virulence and invasion after extracellular stress. Mol Biochem Parasitol 2011; 179(2): 107-110

207. Mayengue PI, Kalmbach Y, Issifou S, Kremsner PG, Ntoumi F. No variation in the prevalence of point mutations in the Pfcrt and Pfmdr1 genes in isolates from Gabonese patients with uncomplicated or severe Plasmodium falciparum malaria. Parasitol Res 2007; 100(3): 487-493.

208. Mixson-Hayden T, Jain V, McCollum AM, Poe A, Nagpal AC, Dash AP et al. Evidence of selective sweeps in genes conferring resistance to chloroquine and pyrimethamine in Plasmodium falciparum isolates in India. Antimicrob Agents Chemother 2010; 54(3): 997-1006.

209. Wélé M, Djimdé AA, Guindo A, Beavogui AH, Traoré IZ, Sadou A et al. High frequency of pfcrt 76T in two Malian villages and its prevalence in severe relative to non-severe malaria. Acta Trop 2011; 119(1): $11-13$. 
210.Ishii A, Matsuoka H, Aji T, Hayatsu H, Wataya Y, Arimoto $\mathrm{S}$ et al. Evaluation of the mutagenicity and the tumor-promoting activity of parasite extracts: Schistosoma japonicum and Clonorchis sinensis. Mutat Res; 1989, 224(2): 229-233.

211. Osada Y, Kumagai T, Masuda K, Suzuki T, Kanazawa T. Mutagenicity evaluation of Schistosoma spp. extracts by the umu-test and V79/HGPRT gene mutation assay. Parasitol Int 2005; 54(1): 29-34.

212.Houzé S, Hubert V, Le Pessec G, Le Bras J, Clain J. Combined deletions of $p f h r p 2$ and $p f h r p 3$ genes result in Plasmodium falciparum malaria false-negative rapid diagnostic test. J Clin Microbiol 2011; 49(7): 2694-2696.

213. Koita OA, Doumbo OK, Ouattara A, Tall LK, Konaré A, Diakité $\mathrm{M}$ et al. False-negative rapid diagnostic tests for malaria and deletion of the histidine-rich repeat region of the hrp2 gene. Am J Trop Med Hyg 2012; 86(2): 194-198.
214.Maltha J, Gamboa D, Bendezu J, Sanchez L, Cnops $\mathrm{L}$, Gillet $\mathrm{P}$ et al. Rapid diagnostic tests for malaria diagnosis in the Peruvian Amazon: impact of pfhrp2 gene deletions and cross-reactions. PLoS One 2012; 7(8): e43094.

215.Kumar N, Pande V, Bhatt RM, Shah NK, Mishra N, Srivastava B et al. Genetic deletion of hrp2 and hrp3 in Indian Plasmodium falciparum population and false negative malaria rapid diagnostic test. Acta Trop 2013; 125(1): 119-121

216. Akinyi S, Hayden T, Gamboa D, Torres K, Bendezu J, Abdallah JF et al. Multiple genetic origins of histidinerich protein 2 gene deletion in Plasmodium falciparum parasites from Peru. Sci Rep 2013; 3: 2797.

217.Abdallah JF, Okoth SA, Fontecha GA, Torres RE, Banegas EI, Matute ML et al. Prevalence of $p f h r p 2$ and pfhrp3 gene deletions in Puerto Lempira, Honduras. Malar J 2015; 14: 19. 